\title{
Investigating self-reported health by occupational group after a 10-year lag: results from the total Belgian workforce
}

\author{
Laura Van den Borre ${ }^{*}$ (i) and Patrick Deboosere
}

\begin{abstract}
Background: Belgium lacks a systematic overview of health differences by occupation. This is the first study to examine self-reported health among 27 occupational groups in Belgium with a lag time of 10 years.

Methods: Individual data are derived from an anonymous linkage between the 1991 and 2001 Belgian census. The total working population (25-55 years) is selected from the 1991 Belgian census. Self-reported health ( 1 = fair or (very) bad health; $0=$ (very) good health) was obtained from the 2001 census. Logistic regression analysis was used to analyse the health of 1.5 million men and 1.0 million women by occupational group in 1991. The active sex-specific population in 1991 and 2001 was the reference group. Controls include age, activity status and housing status at the time of 2001 census.

Results: Both male and female workers in physically demanding occupations were more likely to report poor health. The three occupations with the highest age-adjusted Odds Ratios (OR) were extraction and building trade workers (OR male 2.08 95\% Confidence Interval (Cl) 2.05-2.10; $\mathrm{OR}_{\text {female }} 2.15 \mathrm{Cl}$ 1.93-2.40); services elementary workers ( $\mathrm{OR}_{\text {male }} 2.06 \mathrm{Cl}$ 2.03-2.10; ORfemale $2.37 \mathrm{Cl} 2.34-2.41$ ); and labourers in construction, manufacturing and transport (OR male $1.90 \mathrm{Cl}$ 1.86-1.93; ORfemale $2.21 \mathrm{Cl}$ 2.12-2.29). Men and women in teaching, scientific, health-related and managerial positions had the lowest ageadjusted ORs for poor self-reported health. The pattern in occupational health differences remained the same after controlling for activity status and socio-economic position.

Conclusions: Occupational health inequalities are apparent after a lag time of 10 years. The identification of types of workers in poor health provide valuable insights to future health promotion strategies in the Belgian workforce.
\end{abstract}

Keywords: Cohort study, Occupational health, Self-rated health, Men, Women, Occupation, Health inequalities

\section{Background}

Belgium has no systematic overview of occupational health differences. Yet, this issue is becoming increasingly important as policy measures are being developed to encourage workers to stay employed longer. Considering the importance of deteriorating health as a motive to leave employment [1], there is a high need to understand health inequalities in the Belgian workforce.

The available insights have been gained largely from international research. Manual work has been associated with poor health [2-4]. Although manual workers generally have a better health at the start of employment, their health declines more rapidly during working years than

\footnotetext{
* Correspondence: Laura.Van.den.Borre@vub.be

Interface Demography, Department of Sociology, Vrije Universiteit Brussel,

Pleinlaan 2, 1050 Brussels, Belgium
}

non-manual workers' health [2, 4]. Longitudinal studies show that work-related health differences persist even after job changes or retirement [5]. Not only do manual workers have more years in poor health, they also have shorter life expectancies [6, 7]. Differences are explained partly by the physical demands of manual labour.

Research has been conducted on occupational health in Belgium, but the focus laid mainly on specific work-related diseases $[8,9]$, specific work contexts $[10,11]$ or mechanisms of health differences $[12,13]$. Very little is known about health in specific occupations or how occupational health differences relate to each other. Which occupations have the best health situation? Which workers experience the most health problems? How large is occupational variation in health among Belgian workers?

(c) The Author(s). 2018 Open Access This article is distributed under the terms of the Creative Commons Attribution 4.0 International License (http://creativecommons.org/licenses/by/4.0/), which permits unrestricted use, distribution, and 
This study follows the total Belgian workforce of 1991 using newly available census-linked data to investigate variations in self-reported health for specific occupational groups after a lag time of 10 years. Self-reported health is a well-established predictor of morbidity and mortality, covering physical, mental and social aspects of health $[14,15]$. This research examines potential health differences by occupation in the total male and female working population. We further explore if and to what extent these results differ by age, activity status and socio-economic position.

\section{Method}

Data were derived from an anonymous record linkage between the Belgian censuses of 1991 and 2001. Statistics Belgium performed the linkage at the individual level using unique identification numbers for each citizen. An additional linkage with the population register was performed to account for migrations or deaths between the census dates [16]. The result is a rich, exhaustive dataset combining cross-sectional data at the time of the 1991 and 2001 census. The total Belgian working population aged 25 to 55 years was selected from the 1991 census and followed up until the 2001 census. A total of 1.7 million men and 1.1 million women were employed on 1 March 1991. In the period between the two censuses, $3.1 \%$ of male workers and $1.5 \%$ of female workers died. An overview of the number of deaths per occupation can be found in Table 3 in Appendix. Loss to follow-up due to emigration was $2.1 \%$ and $1.4 \%$ in the male and female working population, respectively. As a result, analyses are based on data from 1.5 million men and 1.0 million women who were at work on 1 March 1991 and resided in Belgium on 1 October 2001.

Health information was derived from the 2001 census using the question 'How is your health in general?' Self-reported health was dichotomized into good (very good/ good coded 0) and poor (fair/bad/very bad coded 1) health. Health questions were not included in the 1991 census.

Occupational groups were composed using the 2-digit codes from the International Standard Classification of Occupations (ISCO-88) as recorded in the 1991 census. The ISCO codes discern skill levels and skill specialisation, referring to the level of complexity and the type of knowledge, tools and equipment used, respectively [17]. Persons working in sheltered workshops were not included because of the targeted health selection in specific industries, corresponding to 7368 disabled men and 4945 disabled women. Both among men and women, the largest occupational group is 'office clerks' with respectively $12 \%$ of working men and $23 \%$ of working women. Other important occupational groups for men include 'extraction and building trades' and 'metal, machinery and related trades', with both employing approximately
9\% of working men. Among women, we find a substantial number of women working in elementary services (11\%) and in professional teaching jobs (11\%).

Tables 4 and 5 in Appendix provide a comprehensive overview of the classification for men and women. Detailed occupational information is not available for 2001. The dataset does include information on the activity status in 2001. Respondents were asked to which category of persons they belong. Possible answers included students, actively employed persons, first-time jobseekers, other unemployed and (early) retirees. We used this information to determine who is still active, unemployed, (pre)retired or inactive due to personal, health or familial reasons.

Logistic regression analyses were performed for poor self-reported health by occupational group. Analyses were performed for men and women separately due to well-established sex differences in the distribution of risk factors for poor self-reported health [18]. Odds Ratios (OR) and 95\% Confidence Intervals (CI) were computed with the sex-specific population that is still actively employed in 2001 as reference population. The majority of the active population in 1991 was still employed ten years later with $75 \%$ of men and $70 \%$ of women. These groups represent the healthiest individuals and provide an insight in the "acceptable" health situation to remain actively employed.

Analyses were performed using STATA/MP version 13.1. Three control variables were added step-wise. First, all models controlled for age measured continuous in years at the time of the 2001 census. Age is an important factor as health deteriorates as people grow older [19].

Second, activity status in 2001 was also included as a control to investigate the associations between poor self-reported health and the transition into the non-active population. Several mechanisms can play a role in the association between activity status and health [20]. Workers may leave employment because of a work-related disease. In the case of a non-occupational disease, workers may also have to leave employment because working conditions have become too strenuous or because of the gravity of the condition.

Third, socio-economic background was examined. Multiple studies have reported an association between poor health and low socio-economic position (SEP) [2123]. Occupation is an important component of SEP which is a composite measure for an individual's place in the social structure [24]. Because the workplace is an important source of social determinants of health, work is potentially closely related to various other material and social indicators [25]. Careful consideration of the socio-economic background is warranted when investigating occupational health differences [26]. Information on housing and ownership was used for this purpose. Housing conditions may have direct health effects [27]. In addition, housing status has also been reported to be a good indicator for material circumstances as it entails 
past (e.g. inheritance), present (e.g. wage) and future (e.g. mortgage) income perspectives [28]. The variable combines information on housing comfort and home ownership at the time of the 2001 census. Tenants and home owners with low, medium and high housing comfort were distinguished. Homes with low comfort require large repairs. Mid- and high-quality homes have central heating and are $>35 \mathrm{~m}^{2}$ and $>85 \mathrm{~m}^{2}$, respectively.

\section{Results}

Table 1 presents the number and share of persons in poor health among the 1991 Belgian workforce with a 10-year lag. Generally, two out of ten workers reported their health to be poor ten years later (men 23\%; women 21\%). For men, the highest percentage was found among services elementary occupations (31\%) and extraction and building trades workers (31\%). The mean age for both occupational groups was 48 years in 2001, which is slightly lower than the total male average. For women, services elementary occupations had the highest share for reporting poor health (32\%). This occupational group is a little older than average with a mean age of 49 in 2001.

The occupational groups with the fewest workers reporting poor health in 2001 were scientific professions. Approximately $10 \%$ of workers in physical, mathematical and engineering science reported poor health (men 11\%; women 9\%). We found a similar result among life science and health professionals (men 11\%; women 14\%).

Figures 1 and 2 present the share of persons in poor health per occupational group in 1991 and by activity status in 2001. The results for men show a clear gradient by activity status. Percentages were highest among those who left employment because of personal reasons with results ranging from $63 \%$ for armed forces and $94 \%$ for agricultural labourers. Unemployed men had a higher relative share for poor health than retired men. One exception to the pattern was found among agricultural labourers, where retired workers (68\%) had a higher share to report poor health than unemployed workers (45\%). Workers that were still active had the lowest percentages from $9 \%$ among physical, mathematical and engineering professionals to $22 \%$ among service elementary workers.

The pattern for women was more condensed than for men, meaning the shares by activity status do not differ as much among women as among men. This is mostly because of the relatively low share of women to report poor health after they left employment due to personal reasons. Percentages for this group ranged between $21 \%$ for physical, mathematical and engineering professionals and $62 \%$ for labourers in construction, manufacturing and transport. Results for unemployed women were highly similar to the findings for retirees. Again, active workers had the lowest share to report poor health with
$7 \%$ of physical, mathematical and engineering professionals and $21 \%$ of agricultural labourers.

Table 2 presents ORs for poor self-reported health by sex. Predictor variables in model1 are respondents' 1991 occupational group and their age at the time of the 2001 census. Model 2 adds the activity status in 2001 and model 3 finally adds the housing status in 2001 .

Occupational variation in ORs for poor self-reported health was similar for men and women. Compared to active workers in both 1991 and 2001, working in services elementary occupations, craft and construction was associated with an increased likelihood to report poor health. The three occupations with the highest age-adjusted ORs were extraction and building trade workers $\left(\mathrm{OR}_{\text {male }} 2.08 \mathrm{CI} 2.05-2.10\right.$; $\mathrm{OR}_{\text {female }} 2.15 \mathrm{CI} 1.93-$ 2.40); services elementary workers $\left(\mathrm{OR}_{\text {male }} 2.06 \mathrm{CI} 2.03-\right.$ 2.10; $\mathrm{OR}_{\text {female }} 2.37 \mathrm{CI} 2.34-2.41$ ); and labourers in mining, construction, manufacturing and transport $\left(\mathrm{OR}_{\text {male }} 1.90 \mathrm{CI}\right.$ 1.86-1.93; $\mathrm{OR}_{\text {female }} 2.21$ CI 2.12-2.29). Men and women in teaching, scientific, health-related and managerial positions had lower age-adjusted ORs for poor self-reported health. Among women, the lowest ORs were found among physical, mathematical and engineering science professionals with 0.71 (CI 0.65-0.77). Their male colleagues had a similar OR (0.61 CI 0.59-0.63), but the lowest OR among men was found among life science and health professionals with 0.59 (CI 0.57-0.61).

The pattern in health differences by occupational group remained clear after controlling for activity status and housing status in 2001.The inclusion of activity status caused ORs in model 2 to decrease considerably for all occupational groups. Compared to workers that were still active in 2001, non-active statuses consistently had higher ORs for poor self-reported health. Leaving employment because of health, familial or other personal reasons was associated with the highest ORs for poor health. Generally, unemployed men and women had higher ORs than retirees with reference to the active population. ORs for occupations converged slightly in model 3 after adding housing status to the model. People living in low-quality housing were more likely to report poor health than those who live in high-quality housing. Home owners had lower ORs than tenants.

\section{Discussion}

This study investigated census-linked data to examine differences in health by occupation among the total Belgian workforce in 1991. The main aim of this research was to provide an overview of self-reported health status in 2001 among 27 occupational groups with a 10-year lag. We found large health inequalities in the Belgian workforce for both sexes, especially in lower qualified occupations. Our results indicate that workers in physically demanding jobs had an increased likelihood to report poor health 
Table 1 Poor self-reported health as reported in the 2001 Belgian census by occupational group at the time of the 1991 Belgian census

\begin{tabular}{|c|c|c|c|c|c|c|c|c|}
\hline \multirow[t]{2}{*}{ Occupational group in 1991 (ISCO code) } & \multicolumn{4}{|l|}{ Men } & \multicolumn{4}{|l|}{ Women } \\
\hline & N 2001 & Age & $\mathrm{SRH}$ & $\mathrm{SRH} \%$ & N 2001 & Age & $\mathrm{SRH}$ & $\mathrm{SRH} \%$ \\
\hline Legislators and senior officials (11) & 4291 & 53 & 703 & $16 \%$ & 1213 & 51 & 201 & $17 \%$ \\
\hline Corporate managers (12) & 129,042 & 51 & 20,476 & $16 \%$ & 39,553 & 49 & 6949 & $18 \%$ \\
\hline Managers of small enterprises (13) & 58,998 & 50 & 14,422 & $24 \%$ & 37,197 & 50 & 9776 & $26 \%$ \\
\hline Physical, math. and engin. science professionals (21) & 43,288 & 47 & 4721 & $11 \%$ & 6691 & 42 & 582 & $9 \%$ \\
\hline Life science and health professionals (22) & 28,794 & 48 & 3264 & $11 \%$ & 71,199 & 46 & 9811 & $14 \%$ \\
\hline Teaching professionals (23) & 65,059 & 51 & 12,410 & $19 \%$ & 109,756 & 49 & 19,031 & $17 \%$ \\
\hline Other professionals (24) & 54,424 & 49 & 8736 & $16 \%$ & 40,270 & 47 & 6137 & $15 \%$ \\
\hline Physical and engin. science assoc. professionals (31) & 114,747 & 50 & 23,736 & $21 \%$ & 18,953 & 47 & 3243 & $17 \%$ \\
\hline Life science and health assoc. professionals (32) & 10,238 & 48 & 1358 & $13 \%$ & 20,738 & 46 & 2832 & $14 \%$ \\
\hline Teaching associate professionals (33) & 7924 & 48 & 1459 & $18 \%$ & 15,560 & 47 & 2915 & $19 \%$ \\
\hline Other associate professionals (34) & 58,711 & 49 & 10,419 & $18 \%$ & 37,696 & 48 & 5995 & $16 \%$ \\
\hline Office clerks (41) & 182,752 & 49 & 37,729 & $21 \%$ & 233,708 & 47 & 41,732 & $18 \%$ \\
\hline Customer services clerks (42) & 6389 & 48 & 1247 & $20 \%$ & 24,206 & 47 & 5233 & $22 \%$ \\
\hline Personal and protective services workers (51) & 58,194 & 48 & 13,694 & $24 \%$ & 83,322 & 47 & 21,686 & $26 \%$ \\
\hline Salespersons and demonstrators (52) & 22,889 & 47 & 4686 & $20 \%$ & 65,966 & 47 & 14,299 & $22 \%$ \\
\hline Skilled agricultural and related workers (61) & 37,704 & 50 & 9499 & $25 \%$ & 13,147 & 52 & 3379 & $26 \%$ \\
\hline Extraction and building trades workers (71) & 134,765 & 48 & 41,308 & $31 \%$ & 1622 & 48 & 470 & $29 \%$ \\
\hline Metal, machinery and related trades workers (72) & 131,878 & 48 & 34,250 & $26 \%$ & 11,241 & 47 & 2973 & $26 \%$ \\
\hline Precision, (handi-)craft and related trades workers (73) & 20,021 & 49 & 5059 & $25 \%$ & 4509 & 46 & 1013 & $22 \%$ \\
\hline Other craft and related trades workers (74) & 43,324 & 48 & 11,153 & $26 \%$ & 28,683 & 47 & 7128 & $25 \%$ \\
\hline Stationary plant and related operators (81) & 23,014 & 48 & 6014 & $26 \%$ & 2010 & 48 & 573 & $29 \%$ \\
\hline Machine operators and assemblers (82) & 40,326 & 48 & 10,489 & $26 \%$ & 28,904 & 46 & 7445 & $26 \%$ \\
\hline Drivers and mobile plant operators (83) & 98,848 & 49 & 28,029 & $28 \%$ & 2586 & 47 & 706 & $27 \%$ \\
\hline Services elementary occupations (91) & 60,491 & 49 & 18,779 & $31 \%$ & 114,190 & 49 & 37,012 & $32 \%$ \\
\hline Agricultural and related labourers (92) & 431 & 43 & 96 & $22 \%$ & 2136 & 53 & 637 & $30 \%$ \\
\hline Labourers in mining, constr., manuf. \& transport (93) & 79,761 & 48 & 22,627 & $28 \%$ & 13,648 & 47 & 3889 & $28 \%$ \\
\hline Armed forces (100) & 24,288 & 46 & 4344 & $18 \%$ & 1890 & 44 & 344 & $18 \%$ \\
\hline Total & $1,540,591$ & 49 & 350,707 & $23 \%$ & $1,030,594$ & 48 & 215,991 & $21 \%$ \\
\hline
\end{tabular}

Abbreviations: N2001 Study population census 2001, Age Mean age in 2001 in years, SRH absolute number of persons reporting poor health in 2001, SRH\% percentage of persons reporting poor health from the 2001 population

with reference to the active population in 1991 and 2001. Considerable variation existed within manual jobs as age-adjusted ORs ranged between approximately 1.40 and 2.00. Even higher results were observed among women, where age-adjusted ORs were up to 2.37 (CI 2.34-2.41) for services elementary occupations. Teaching, health-related and managerial jobs were associated with lower ORs for poor self-reported health. The pattern in occupational health differences remained the same after controlling for activity status and socio-economic status.

Occupation, age, activity status and housing status explained up to $10 \%$ and $9 \%$ of health differences among men and women, respectively. The largest contribution in explained variance was found after controlling for activity status. Especially ORs among manual workers experienced a stark decline after taking activity status into account. A potential explanation lies in differential healthy worker effects by occupational group [29]. Health problems in late middle age may create a discrepancy between the individual capabilities and the job requirements. Because of the physically demanding nature of manual labour, these workers may be more likely to encounter a mismatch than non-manual workers. In addition, the accumulation of unfavourable working conditions in these occupations has been reported to affect workers' health [30]. As a result, more manual workers may quit their jobs due to health reasons compared to other workers, creating larger health differences by activity status in manual occupations. 


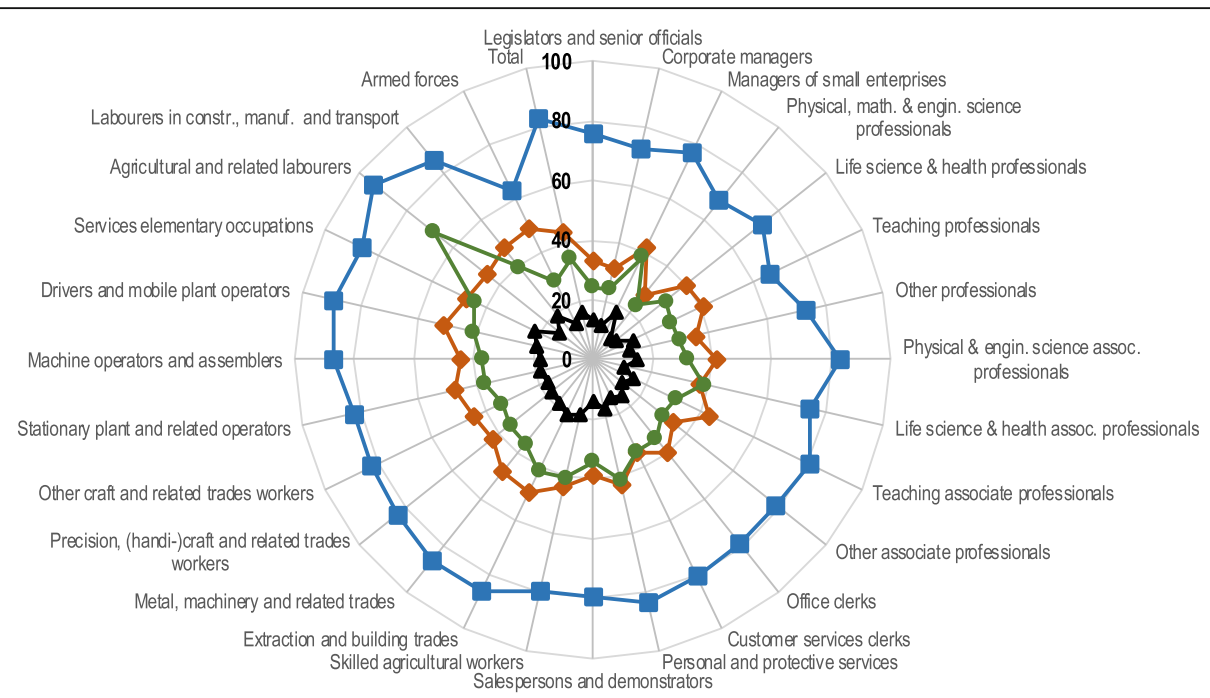

Fig. 1 Percentage of men reporting poor health by occupational group in the 1991 Belgian census and activity status in the 2001 Belgian census. Legend: $\rightarrow$-Active

$\leadsto$ Unemployed

Housing status did not seem to explain much of the differences in self-reported health by occupation. The inclusion of housing status modified ORs only slightly. The largest changes in ORs were among occupational groups with a specific socio-economic profile, such as services elementary occupations with a high proportion of cleaners.

The observed occupational health differences can perhaps be further explained by specific psychosocial or physical working conditions. Schütte and colleagues found that poor self-reported health is associated with hazardous working conditions, as well as with high psychological demands, low rewards and work-life imbalance for both men and women [18]. Several other studies have reported an influence of high job demands, job insecurity and repetitive work on occupational health differences [31-33]. Future research is needed to understand which work-related health risks are of importance for the investigated occupational groups.

The key strength of this study is the availability of a large, exhaustive dataset, which allowed us to study the total 1991 Belgian workforce. High-quality information was drawn from comprehensive and reliable national data sources [34]. The findings for 27 specific occupational groups complement existing international research based on fewer and broader categories. As a result, the findings provide a nuanced overview of occupational health in Belgium for the first time. In addition, this research adds

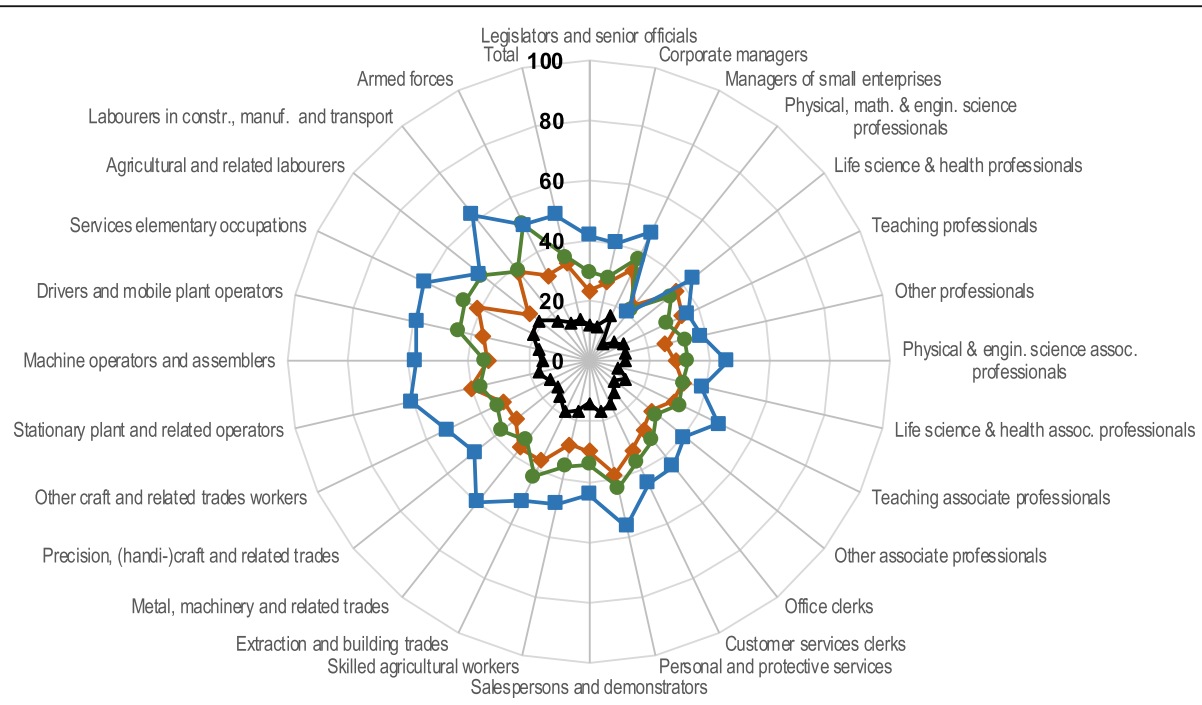

Fig. 2 Percentage of women reporting poor health by occupational group in the 1991 Belgian census and activity status in the 2001 Belgian census. Legend: $\rightarrow$ Active $\quad \sim$ Unemployed 


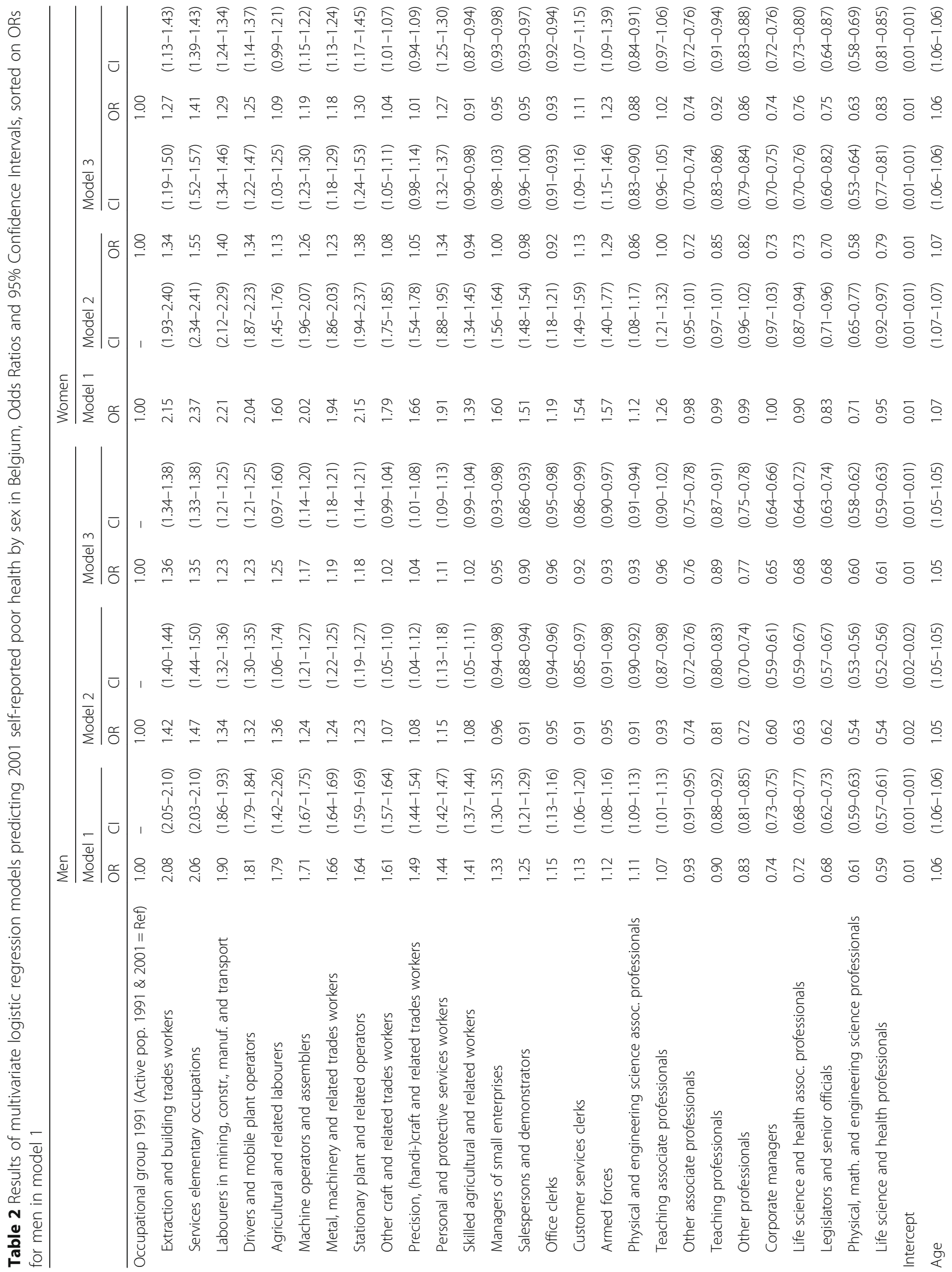




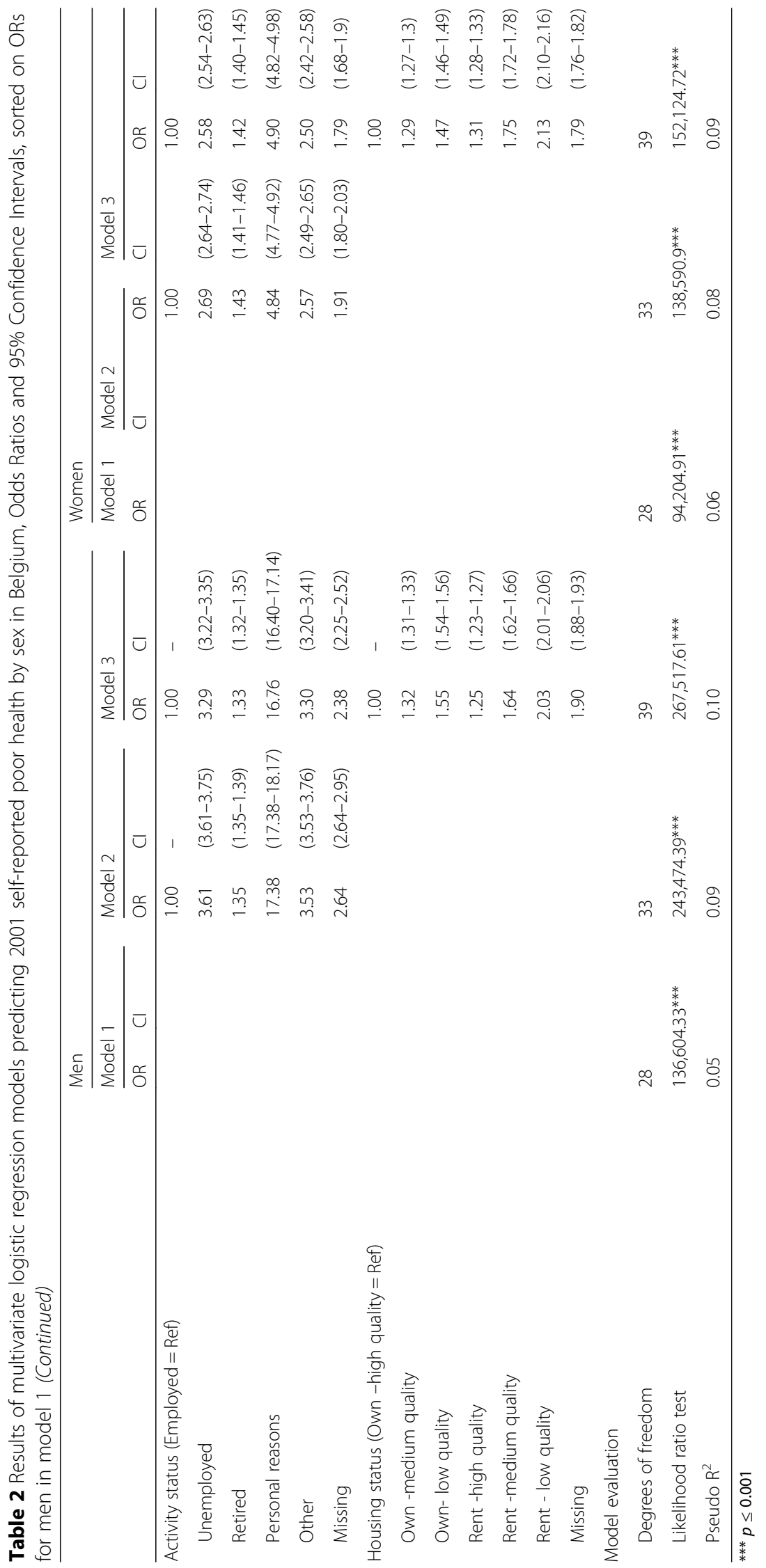


to the growing body of literature on work-related health differences among women. Earlier studies report mixed and contradictory results [4, 6, 19, 35-37]. In accordance with recent French findings [6], we found relatively large occupational differences in women's health. The pattern in self-reported health by occupation is clearly similar for men and women although results cannot be directly compared because of the use of sex-specific reference populations. We observed a difference in self-reported health by activity status between men and women. Men who left employment because of personal, health or familial reasons have markedly higher ORs than women with reference to their respective reference populations. It is highly likely that poor health was the decisive factor for these men in leaving employment. Women in this age group may be more prone to stop working because of familial obligations such as caregiving or childrearing.

The study also has some limitations. Firstly, health was measured using a general self-reported health question. Answers reflect multiple health dimensions and are highly subject to individual perceptions, as well as to the wider socio-temporal context [38]. This entails results should be interpreted with consideration for cross-cultural differences. A common methodological issue with self-reported health is that health experiences affect the response rate. People in poor health may not be fit enough to answer the questions. Self-reported health from the 2001 Belgian census has been compared to the national health interview survey. Lorant and colleagues found fewer non-response and better representation of low socio-economic groups in the -mandatory- census [34].

Secondly, the repeated cross-sectional design does not capture the dynamic mechanisms underlying this complex relation between health and occupation. Previous research has found important effects of time-varying indicators [39, 40]. In this study, specific occupational information is only available for one point in time. Job changes may have occurred over the period of 10 year, which may alter our results slightly. In our opinion, transfers from one occupational group to another in 1991 will be scarce given the use of relatively broad categories of occupations. Health selection in and out of employment has been reported to be more important than changes between jobs [41]. By controlling for activity status in 2001, we have accounted for possible healthy worker effects due to inactivity. However, it is possible that those experiencing very poor health, may have died or emigrated in the 10-year lag period. As a result of this potential underestimation in the worst-off professions, health inequalities between occupational groups may be even larger than presented in this study.

Thirdly, potential effects from part-time and full-time work are not investigated in the present study. An association between poor health and part-time employment has been reported in previous research [42]. It is possible that our results for women may alter somewhat when considering differences in work time. According to the 1991 census, $64 \%$ of working women were employed full-time with proportions ranging from $45 \%$ among customers service clerks to $98 \%$ in the armed forces. In contrast, the overall majority (95\%) of active Belgian men worked full-time in 1991 with little variation across occupations. This topic should be investigated in future research with consideration of the complexities of contextual gender differences (e.g. child rearing tasks, relationship status, different working conditions and welfare state provisions) [43, 44].

Fourthly, the lack of suitable occupational data is a major obstacle for Belgian longitudinal analyses on this topic. The results for the 1991 working population may not reflect current-day differences in health situation by occupation. Although the occupational groups under investigation are still highly relevant, the Belgian workforce has undergone some important socio-demographic and economic changes over the last decades, as most West-European countries [45]. The presented findings are based on the most recent data available for a nationwide analysis of health differences by occupation in Belgium.

This research quantifies an important policy challenge in Belgium. This study shows a continuum of health risks with a clear hierarchy by occupation even after a 10-year lag time. Policy makers should invest in reducing health disparities by occupation. We stress the importance of additional research and policy efforts targeting manual labour jobs.

We also call policymakers' attention to the large health differences by occupation in the female working population, especially considering the increased labour market participation of women during the last decades. According to data from the International Labour Organization, the overall female labour force participation increased from $38 \%$ in 1992 to $48 \%$ in 2017 [46].

\section{Conclusion}

This study provided an overview of health differences among 27 types of Belgian workers. Both male and female workers in physically demanding occupations were more likely to report poor health. Significantly fewer workers in teaching, health-related and managerial jobs reported poor health. Large differences were observed between activity statuses -particularly in men- as found in previous research [20]. The current study confirms earlier findings of a negative association between socio-economic position and poor self-reported health [21-23]. To our knowledge, this is the first Belgian study to provide insights in the health situation by occupation with a ten year-lag. For now, we can only speculate on which health problems are at the root based on these results. Future research is required to determine the underlying mechanisms of the presented occupational health differences. 


\section{Appendix}

Table 3 Population in the 1991 and 2001 Belgian censuses with mortality information in the intermediate period from the National Register

\begin{tabular}{|c|c|c|c|c|c|c|c|c|}
\hline \multirow[t]{2}{*}{ Occupational group in 1991 (ISCO code) } & \multicolumn{4}{|l|}{ Men } & \multicolumn{4}{|l|}{ Women } \\
\hline & N 1991 & D9101 & $\mathrm{D} \%$ & N 2001 & N 1991 & D 9101 & $\mathrm{D} \%$ & N 2001 \\
\hline Legislators \& senior officials (11) & 4342 & 109 & $3 \%$ & 4291 & 1344 & 23 & $2 \%$ & 1213 \\
\hline Corporate managers (12) & 145,563 & 4055 & $3 \%$ & 129,042 & 43,608 & 674 & $2 \%$ & 39,553 \\
\hline Managers of small enterprises (13) & 67,433 & 2508 & $4 \%$ & 58,998 & 41,011 & 915 & $2 \%$ & 37,197 \\
\hline Physical, math. \& engin. Science professionals (21) & 47,276 & 804 & $2 \%$ & 43,288 & 7200 & 56 & $1 \%$ & 6691 \\
\hline Life science \& health professionals (22) & 31,203 & 666 & $2 \%$ & 28,794 & 75,324 & 933 & $1 \%$ & 71,199 \\
\hline Teaching professionals (23) & 69,505 & 1812 & $3 \%$ & 65,059 & 115,784 & 1568 & $1 \%$ & 109,756 \\
\hline Other professionals (24) & 60,675 & 1623 & $3 \%$ & 54,424 & 43,739 & 609 & $1 \%$ & 40,270 \\
\hline Physical \& engin. Science assoc. professionals (31) & 123,646 & 3406 & $3 \%$ & 114,747 & 20,123 & 249 & $1 \%$ & 18,953 \\
\hline Life science \& health assoc. professionals (32) & 11,017 & 260 & $2 \%$ & 10,238 & 21,965 & 268 & $1 \%$ & 20,738 \\
\hline Teaching associate professionals (33) & 8482 & 212 & $2 \%$ & 7924 & 16,454 & 235 & $1 \%$ & 15,560 \\
\hline Other associate professionals (34) & 64,442 & 1915 & $3 \%$ & 58,711 & 40,401 & 540 & $1 \%$ & 37,696 \\
\hline Office clerks (41) & 198,520 & 6333 & $3 \%$ & 182,752 & 248,577 & 3460 & $1 \%$ & 233,708 \\
\hline Customer services clerks (42) & 6891 & 206 & $3 \%$ & 6389 & 25,602 & 322 & $1 \%$ & 24,206 \\
\hline Personal \& protective services workers (51) & 64,538 & 2301 & $4 \%$ & 58,194 & 89,339 & 1249 & $1 \%$ & 83,322 \\
\hline Salespersons \& demonstrators (52) & 25,304 & 748 & $3 \%$ & 22,889 & 70,406 & 931 & $1 \%$ & 65,966 \\
\hline Skilled agricultural \& related workers (61) & 41,208 & 1394 & $3 \%$ & 37,704 & 14,030 & 228 & $2 \%$ & 13,147 \\
\hline Extraction \& building trades workers (71) & 148,321 & 5072 & $3 \%$ & 134,765 & 1766 & 32 & $2 \%$ & 1622 \\
\hline Metal, machinery \& related trades workers (72) & 142,657 & 4209 & $3 \%$ & 131,878 & 11,854 & 157 & $1 \%$ & 11,241 \\
\hline Precision, (handi-)craft \& related trades workers (73) & 21,738 & 695 & $3 \%$ & 20,021 & 4782 & 58 & $1 \%$ & 4509 \\
\hline Other craft \& related trades workers (74) & 47,410 & 1484 & $3 \%$ & 43,324 & 30,334 & 370 & $1 \%$ & 28,683 \\
\hline Stationary plant \&related operators (81) & 24,926 & 806 & $3 \%$ & 23,014 & 2138 & 25 & $1 \%$ & 2010 \\
\hline Machine operators \& assemblers (82) & 43,824 & 1294 & $3 \%$ & 40,326 & 30,562 & 376 & $1 \%$ & 28,904 \\
\hline Drivers \& mobile plant operators (83) & 109,143 & 4130 & $4 \%$ & 98,848 & 2784 & 50 & $2 \%$ & 2586 \\
\hline Services elementary occupations (91) & 67,620 & 2749 & $4 \%$ & 60,491 & 122,441 & 2085 & $2 \%$ & 114,190 \\
\hline Agricultural \& related labourers (92) & 459 & 12 & $3 \%$ & 431 & 2311 & 59 & $3 \%$ & 2136 \\
\hline Labourers in mining, constr., manuf. \& transport (93) & 87,529 & 3226 & $4 \%$ & 79,761 & 14,503 & 179 & $1 \%$ & 13,648 \\
\hline Armed forces (100) & 26,704 & 713 & $3 \%$ & 24,288 & 2004 & 26 & $1 \%$ & 1890 \\
\hline Total & $1,690,376$ & 52,742 & $3 \%$ & $1,540,591$ & $1,100,386$ & 15,677 & $1 \%$ & $1,030,594$ \\
\hline
\end{tabular}


Table 4 Occupational categories in English, Dutch and French [47]

\begin{tabular}{|c|c|c|c|}
\hline $\mathrm{ISCO}$ & English & Dutch & French \\
\hline 11 & $\begin{array}{l}\text { Legislators, senior officials and } \\
\text { managers }\end{array}$ & $\begin{array}{l}\text { Leden van de wetgevende en uitvoerende macht } \\
\text { en hogere kaderleden van het openbaar bestuur }\end{array}$ & $\begin{array}{l}\text { Membres de l'exécutif et des corps législatifs, et } \\
\text { cadres supérieurs de l'administration publique }\end{array}$ \\
\hline 12 & Corporate managers & Bedrijfsleider en hoger kaderpersoneel & Directeurs de société \\
\hline 13 & Managers of small entertprises & Directeurs en beheerders van kleine ondernemingen & Dirigeants et gérants \\
\hline 21 & $\begin{array}{l}\text { Physical, mathematical and } \\
\text { engineering science professionals }\end{array}$ & $\begin{array}{l}\text { Specialisten in de fysische, wiskundige en technische } \\
\text { wetenschappen }\end{array}$ & $\begin{array}{l}\text { Spécialistes des sciences physiques, mathématiques } \\
\text { et techniques }\end{array}$ \\
\hline 22 & $\begin{array}{l}\text { Life science and health } \\
\text { professionals }\end{array}$ & Specialisten in de medische en biowetenschappen & Spécialistes des sciences de la vie et de la santé \\
\hline 23 & Teaching professionals & Specialisten in het onderwijs & Spécialistes de l'enseignement \\
\hline 24 & Other professionals & $\begin{array}{l}\text { Andere specialisten in intellectuele en } \\
\text { wetenschappelijke beroepen }\end{array}$ & $\begin{array}{l}\text { Autres spécialistes des professions intellectuelles et } \\
\text { scientifiques }\end{array}$ \\
\hline 31 & $\begin{array}{l}\text { Physical and engineering science } \\
\text { associate professionals }\end{array}$ & $\begin{array}{l}\text { Ondergeschikt personeel in de fysische, wiskundige } \\
\text { en technische wetenschappen }\end{array}$ & $\begin{array}{l}\text { Professions intermédiaires des sciences physiques } \\
\text { et techniques }\end{array}$ \\
\hline 32 & $\begin{array}{l}\text { Life science an dhealth associate } \\
\text { professionals }\end{array}$ & $\begin{array}{l}\text { Ondergeschikt personeel in de medische } \\
\text { wetenschappen }\end{array}$ & $\begin{array}{l}\text { Professions intermédiaires des sciences de la vie et } \\
\text { de la santé }\end{array}$ \\
\hline 33 & Teaching associate professionals & Ondergeschikt personeel in het onderwijs & Professions intermédiaires de l'enseignement \\
\hline 34 & Other associate professionals & $\begin{array}{l}\text { Ander ondergeschikt personeel in de intellectuele } \\
\text { en wetenschappelijke beroepen }\end{array}$ & Autres professions intermédiaires \\
\hline 41 & Office clerks & Kantoorbedienden & Employés de bureau \\
\hline 42 & Customer servies clerks & Receptionisten, kassiers, loketbedienden en dergelijke & $\begin{array}{l}\text { Employés de réception, caissiers, guichetiers et } \\
\text { assimilés }\end{array}$ \\
\hline 51 & $\begin{array}{l}\text { Personal and protective services } \\
\text { workers }\end{array}$ & Dienstverlenend en veiligheidspersoneel & $\begin{array}{l}\text { Personnel des services directs aux particuliers et } \\
\text { des services de protection et de sécurité }\end{array}$ \\
\hline 52 & $\begin{array}{l}\text { Models, salespersons and } \\
\text { demonstrators }\end{array}$ & Modellen, verkopers en demonstrateurs & Modèles, vendeurs et démonstrateurs \\
\hline 61 & $\begin{array}{l}\text { Skilled argicultural and fishery } \\
\text { workers }\end{array}$ & $\begin{array}{l}\text { Voor de markt producerende landbouwers en } \\
\text { geschoolde arbeiders in de landbouw en de visserij }\end{array}$ & $\begin{array}{l}\text { Agriculteurs et ouvriers qualifiés de l'agriculture et } \\
\text { de la pêche destinées aux marchés }\end{array}$ \\
\hline 71 & $\begin{array}{l}\text { Extraction and building trades } \\
\text { workers }\end{array}$ & $\begin{array}{l}\text { Ambachtslieden en vakarbeiders in de winning } \\
\text { van delfstoffen en de bouwnijverheid }\end{array}$ & $\begin{array}{l}\text { Artisans et ouvriers des métiers de l'extraction et du } \\
\text { bâtiment }\end{array}$ \\
\hline 72 & $\begin{array}{l}\text { Metal,machinery and related } \\
\text { trades workers }\end{array}$ & $\begin{array}{l}\text { Ambachtslieden en vakarbeiders in de metallurgie, } \\
\text { de metaalverwerkende nijverheid, de machinebouw } \\
\text { en dergelijke }\end{array}$ & $\begin{array}{l}\text { Artisans et ouvriers des métiers de la métallurgie, } \\
\text { de la construction mécanique et assimilés }\end{array}$ \\
\hline 73 & $\begin{array}{l}\text { Precision, handicraft, craft printing } \\
\text { and related trades workers }\end{array}$ & $\begin{array}{l}\text { Ambachtslieden en vakarbeiders in de } \\
\text { precisienijverheid, het kunstambacht, de drukkerijen } \\
\text { en dergelijke }\end{array}$ & $\begin{array}{l}\text { Artisans et ouvriers de la mécanique de précision, } \\
\text { des métiers d'art, de l'imprimerie et assimilés }\end{array}$ \\
\hline 74 & $\begin{array}{l}\text { Other craft and related trades } \\
\text { workers }\end{array}$ & $\begin{array}{l}\text { Andere ambachtslieden en ambachtelijke } \\
\text { vakarbeiders }\end{array}$ & $\begin{array}{l}\text { Autres artisans et ouvriers des métiers de type } \\
\text { artisanal }\end{array}$ \\
\hline 81 & $\begin{array}{l}\text { Stationary-plant and related } \\
\text { operators }\end{array}$ & Fabrieksarbeiders aan vaste installaties en dergelijke & $\begin{array}{l}\text { Conducteurs d'installations et de matériels fixes et } \\
\text { assimilés }\end{array}$ \\
\hline 82 & $\begin{array}{l}\text { Machine operators and } \\
\text { assemblers }\end{array}$ & Machine- en montage-arbeiders & $\begin{array}{l}\text { Conducteurs de machines et ouvriers de } \\
\text { l'assemblage }\end{array}$ \\
\hline 83 & $\begin{array}{l}\text { Drivers and mobile plant } \\
\text { operators }\end{array}$ & $\begin{array}{l}\text { Bestuurders van voertuigen, hijs-, hef- en } \\
\text { transportwerktuigen }\end{array}$ & $\begin{array}{l}\text { Conducteurs de véhicules et d'engins lourds de } \\
\text { levage et de manœuvre }\end{array}$ \\
\hline 91 & $\begin{array}{l}\text { Sales and services elementary } \\
\text { occupations }\end{array}$ & Ongeschoold dienstverlenend en verkoopspersoneel & Employés non qualifiés des services et de la vente \\
\hline 92 & $\begin{array}{l}\text { Agricultural, fishery and related } \\
\text { labourers }\end{array}$ & $\begin{array}{l}\text { Ongeschoolde arbeiders in de landbouw, visserij } \\
\text { en dergelijke }\end{array}$ & $\begin{array}{l}\text { Manœuvres de l'agriculture, de la pêche et } \\
\text { assimilés }\end{array}$ \\
\hline 93 & $\begin{array}{l}\text { Labourers in mining, } \\
\text { constructions, manufacturing } \\
\text { and transport }\end{array}$ & $\begin{array}{l}\text { Ongeschoolde arbeiders in de mijnbouw, de } \\
\text { bouwnijverheid, de verwerkende nijverheid en } \\
\text { het transport }\end{array}$ & $\begin{array}{l}\text { Manœuvres des mines, du bâtiment et des travaux } \\
\text { publics, des industries manufacturières et des } \\
\text { transports }\end{array}$ \\
\hline 110 & Armed forces & Strijdkrachten & Forces armées \\
\hline
\end{tabular}


Table 5 Study population by sex and occupation in the 1991 Belgian census

\begin{tabular}{|c|c|c|c|c|c|}
\hline $\mathrm{ISCO}$ & Occupational group in 1991 & M & $M \%$ & $\mathrm{~F}$ & $\mathrm{~F} \%$ \\
\hline 11 & Legislators and senior officials & 4427 & 100.0 & 1269 & 100.0 \\
\hline 1110 & Legislators & 129 & 2.9 & 59 & 4.6 \\
\hline 1120 & Senior government officials & 3384 & 76.4 & 1043 & 82.2 \\
\hline 1141 & Senior officials of political-party organisations & 12 & 0.3 & 11 & 0.9 \\
\hline 1142 & $\begin{array}{l}\text { Senior officials of employers', workers' and other economic-interest } \\
\text { organisations }\end{array}$ & 380 & 8.6 & 74 & 5.8 \\
\hline 1143 & Senior officials of humanitarian and other special-interest organisations & 170 & 3.8 & 82 & 6.5 \\
\hline 110 & Senior army officials & 352 & 8.0 & 0 & 0.0 \\
\hline 12 & Corporate managers & 134,047 & 100.0 & 41,217 & 100.0 \\
\hline 1210 & Directors and chief executives & 57,924 & 43.2 & 14,808 & 35.9 \\
\hline 1221 & $\begin{array}{l}\text { Production and operations department managers in agriculture, } \\
\text { hunting, forestry and fishing }\end{array}$ & 43 & 0.0 & 18 & 0.0 \\
\hline 1224 & $\begin{array}{l}\text { Production and operations department managers in wholesale and } \\
\text { retail trade }\end{array}$ & 1425 & 1.1 & 704 & 1.7 \\
\hline 1225 & $\begin{array}{l}\text { Production and operations department managers in restaurants } \\
\text { and hotels }\end{array}$ & 93 & 0.1 & 38 & 0.1 \\
\hline 1229 & $\begin{array}{l}\text { Production and operations department managers not elsewhere } \\
\text { classified }\end{array}$ & 17,374 & 13.0 & 6713 & 16.3 \\
\hline 1231 & Finance and administration department managers & 5951 & 4.4 & 752 & 1.8 \\
\hline 1232 & Personnel and industrial relations department managers & 5108 & 3.8 & 1355 & 3.3 \\
\hline 1233 & Sales and marketing department managers & 18,569 & 13.9 & 9097 & 22.1 \\
\hline 1235 & Supply and distribution department managers & 162 & 0.1 & 24 & 0.1 \\
\hline 1236 & Computing services department managers & 1199 & 0.9 & 153 & 0.4 \\
\hline 1237 & Research and development department managers & 2069 & 1.5 & 1169 & 2.8 \\
\hline 1239 & Other department managers not elsewhere classified & 24,130 & 18.0 & 6386 & 15.5 \\
\hline 13 & Managers of small enterprises & 62,531 & 100.0 & 39,141 & 100.0 \\
\hline 1311 & General managers in agriculture, hunting, forestry and fishing & 2521 & 4.0 & 652 & 1.7 \\
\hline 1312 & General managers in manufacturing & 126 & 0.2 & 6 & 0.0 \\
\hline 1313 & General managers in construction & 4124 & 6.6 & 55 & 0.1 \\
\hline 1314 & General managers in wholesale and retail trade & 33,613 & 53.8 & 22,691 & 58.0 \\
\hline 1315 & General managers of restaurants and hotels & 12,922 & 20.7 & 12,247 & 31.3 \\
\hline 1317 & General managers of business services & 87 & 0.1 & 28 & 0.1 \\
\hline 1318 & General managers in personal care, cleaning and related services & 395 & 0.6 & 869 & 2.2 \\
\hline 1319 & General managers not elsewhere classified & 8743 & 14.0 & 2593 & 6.6 \\
\hline 21 & Physical, mathematical and engineering science professionals & 44,553 & 100.0 & 6876 & 100.0 \\
\hline 2111 & Physicists and astronomers & 79 & 0.2 & 43 & 0.6 \\
\hline 2112 & Meteorologists & 18 & 0.0 & 3 & 0.0 \\
\hline 2113 & Chemists & 274 & 0.6 & 104 & 1.5 \\
\hline 2114 & Geologists and geophysicists & 117 & 0.3 & 27 & 0.4 \\
\hline 2121 & Mathematicians and related professionals & 87 & 0.2 & 51 & 0.7 \\
\hline 2122 & Statisticians & 50 & 0.1 & 28 & 0.4 \\
\hline 2131 & Computer systems designers and analysts & 11,535 & 25.9 & 2071 & 30.1 \\
\hline 2132 & Computer programmers & 7968 & 17.9 & 2206 & 32.1 \\
\hline 2139 & Computing professionals not elsewhere classified & 1251 & 2.8 & 94 & 1.4 \\
\hline 2141 & Architects, town and traffic planners & 5451 & 12.2 & 1384 & 20.1 \\
\hline 2142 & Civil engineers & 1489 & 3.3 & 73 & 1.1 \\
\hline
\end{tabular}


Table 5 Study population by sex and occupation in the 1991 Belgian census (Continued)

\begin{tabular}{|c|c|c|c|c|c|}
\hline ISCO & Occupational group in 1991 & M & $\mathrm{M} \%$ & $\mathrm{~F}$ & $\mathrm{~F} \%$ \\
\hline 2143 & Electrical engineers & 454 & 1.0 & 7 & 0.1 \\
\hline 2144 & Electronics and telecommunications engineers & 952 & 2.1 & 29 & 0.4 \\
\hline 2145 & Mechanical engineers & 196 & 0.4 & 2 & 0.0 \\
\hline 2146 & Chemical engineers & 397 & 0.9 & 78 & 1.1 \\
\hline 2147 & Mining engineers, metallurgists and related professionals & 49 & 0.1 & 2 & 0.0 \\
\hline 2148 & Cartographers and surveyors & 1204 & 2.7 & 77 & 1.1 \\
\hline 2149 & $\begin{array}{l}\text { Architects, engineers and related professionals not elsewhere } \\
\text { classified }\end{array}$ & 12,982 & 29.1 & 597 & 8.7 \\
\hline 22 & Life science and health professionals & 29,762 & 100.0 & 73,403 & 100.0 \\
\hline 2211 & Biologists, botanists, zoologists and related professionals & 198 & 0.7 & 166 & 0.2 \\
\hline 2212 & Pharmacologists, pathologists and related professionals & 95 & 0.3 & 58 & 0.1 \\
\hline 2213 & Agronomists and related professionals & 411 & 1.4 & 72 & 0.1 \\
\hline 2221 & Medical doctors & 14,166 & 47.6 & 4934 & 6.7 \\
\hline 2222 & Dentists & 2988 & 10.0 & 1882 & 2.6 \\
\hline 2223 & Veterinarians & 1674 & 5.6 & 422 & 0.6 \\
\hline 2224 & Pharmacists & 2347 & 7.9 & 3510 & 4.8 \\
\hline 2230 & Nursing and midwifery professionals & 7883 & 26.5 & 62,359 & 85.0 \\
\hline 23 & Teaching professionals & 66,821 & 100.0 & 113,020 & 100.0 \\
\hline 2310 & College, university and higher education teaching professionals & 4179 & 6.3 & 2064 & 1.8 \\
\hline 2320 & Secondary education teaching professionals & 46,849 & 70.1 & 58,862 & 52.1 \\
\hline 2331 & Primary education teaching professionals & 13,401 & 20.1 & 30,806 & 27.3 \\
\hline 2332 & Pre-primary education teaching professionals & 402 & 0.6 & 18,886 & 16.7 \\
\hline 2340 & Special education teaching professionals & 627 & 0.9 & 1171 & 1.0 \\
\hline 2351 & Education methods specialists & 331 & 0.5 & 523 & 0.5 \\
\hline 2352 & School inspectors & 217 & 0.3 & 68 & 0.1 \\
\hline 2359 & Other teaching professionals not elsewhere classified & 815 & 1.2 & 640 & 0.6 \\
\hline 24 & Other professionals & 56,647 & 100.0 & 41,848 & 100.0 \\
\hline 2411 & Accountants & 15,150 & 26.7 & 9020 & 21.6 \\
\hline 2412 & Personnel and careers professionals & 1344 & 2.4 & 603 & 1.4 \\
\hline 2419 & Business professionals not elsewhere classified & 5728 & 10.1 & 2234 & 5.3 \\
\hline 2421 & Lawyers & 5629 & 9.9 & 2909 & 7.0 \\
\hline 2422 & Judges & 807 & 1.4 & 342 & 0.8 \\
\hline 2429 & Legal professionals not elsewhere classified & 1913 & 3.4 & 827 & 2.0 \\
\hline 2431 & Archivists and curators & 173 & 0.3 & 133 & 0.3 \\
\hline 2432 & Librarians and related information professionals & 1027 & 1.8 & 2135 & 5.1 \\
\hline 2441 & Economists & 222 & 0.4 & 83 & 0.2 \\
\hline 2442 & Sociologists, anthropologists and related professionals & 134 & 0.2 & 129 & 0.3 \\
\hline 2443 & Philosophers, historians and political scientists & 10 & 0.0 & 16 & 0.0 \\
\hline 2444 & Philologists, translators and interpreters & 868 & 1.5 & 1062 & 2.5 \\
\hline 2445 & Psychologists & 1091 & 1.9 & 1990 & 4.8 \\
\hline 2446 & Social work professionals & 4350 & 7.7 & 11,339 & 27.1 \\
\hline 2451 & Authors, journalists and other writers & 2938 & 5.2 & 1203 & 2.9 \\
\hline 2452 & Sculptors, painters and related artists & 2990 & 5.3 & 2135 & 5.1 \\
\hline 2453 & Composers, musicians and singers & 1049 & 1.9 & 367 & 0.9 \\
\hline
\end{tabular}


Table 5 Study population by sex and occupation in the 1991 Belgian census (Continued)

\begin{tabular}{|c|c|c|c|c|c|}
\hline ISCO & Occupational group in 1991 & M & $\mathrm{M} \%$ & $\mathrm{~F}$ & $\mathrm{~F} \%$ \\
\hline 2454 & Choreographers and dancers & 29 & 0.1 & 93 & 0.2 \\
\hline 2455 & Film, stage and related actors and directors & 830 & 1.5 & 454 & 1.1 \\
\hline 2460 & Religious professionals & 1419 & 2.5 & 74 & 0.2 \\
\hline 2470 & Public service administrative professionals & 8946 & 15.8 & 4700 & 11.2 \\
\hline 31 & Physical and engineering science associate professionals & 118,132 & 100.0 & 19,564 & 100.0 \\
\hline 3111 & Chemical and physical science technicians & 1155 & 1.0 & 514 & 2.6 \\
\hline 3112 & Civil engineering technicians & 929 & 0.8 & 44 & 0.2 \\
\hline 3113 & Electrical engineering technicians & 8355 & 7.1 & 188 & 1.0 \\
\hline 3114 & Electronics and telecommunications engineering technicians & 2596 & 2.2 & 93 & 0.5 \\
\hline 3115 & Mechanical engineering technicians & 4763 & 4.0 & 128 & 0.7 \\
\hline 3116 & Chemical engineering technicians & 8189 & 6.9 & 8881 & 45.4 \\
\hline 3118 & Draughtspersons & 11,263 & 9.5 & 1401 & 7.2 \\
\hline 3119 & Physical and engineering science technicians not elsewhere classified & 66,313 & 56.1 & 5414 & 27.7 \\
\hline 3122 & Computer equipment operators & 1870 & 1.6 & 100 & 0.5 \\
\hline 3131 & Photographers and image and sound recording equipment operators & 2308 & 2.0 & 647 & 3.3 \\
\hline 3132 & Broadcasting and telecommunications equipment operators & 977 & 0.8 & 97 & 0.5 \\
\hline 3133 & Medical equipment operators & 350 & 0.3 & 479 & 2.4 \\
\hline 3141 & Ships' engineers & 333 & 0.3 & 1 & 0.0 \\
\hline 3142 & Ships' deck officers and pilots & 1882 & 1.6 & 303 & 1.5 \\
\hline 3143 & Aircraft pilots and related associate professionals & 600 & 0.5 & 31 & 0.2 \\
\hline 3144 & Air traffic controllers & 536 & 0.5 & 80 & 0.4 \\
\hline 3152 & Safety, health and quality inspectors & 5713 & 4.8 & 1163 & 5.9 \\
\hline 32 & Life science and health associate professionals & 10,549 & 100.0 & 21,365 & 100.0 \\
\hline 3211 & Life science technicians & 101 & 1.0 & 57 & 0.3 \\
\hline 3212 & Agronomy and forestry technicians & 203 & 1.9 & 16 & 0.1 \\
\hline 3213 & Farming and forestry advisers & 76 & 0.7 & 16 & 0.1 \\
\hline 3221 & Medical assistants & 270 & 2.6 & 2300 & 10.8 \\
\hline 3222 & Sanitarians & 53 & 0.5 & 42 & 0.2 \\
\hline 3223 & Dieticians and nutritionists & 70 & 0.7 & 877 & 4.1 \\
\hline 3224 & Optometrists and opticians & 1011 & 9.6 & 448 & 2.1 \\
\hline 3225 & Dental assistants & 921 & 8.7 & 207 & 1.0 \\
\hline 3226 & Physiotherapists and related associate professionals & 6261 & 59.4 & 9030 & 42.3 \\
\hline 3228 & Pharmaceutical assistants & 569 & 5.4 & 3446 & 16.1 \\
\hline 3229 & $\begin{array}{l}\text { Modern health associate professionals (except nursing) not } \\
\text { elsewhere classified }\end{array}$ & 359 & 3.4 & 2555 & 12.0 \\
\hline 3231 & Nursing associate professionals & 634 & 6.0 & 2359 & 11.0 \\
\hline 3242 & Faith healers & 21 & 0.2 & 12 & 0.1 \\
\hline 33 & Teaching associate professionals & 8161 & 100.0 & 16,065 & 100.0 \\
\hline 3310 & Primary education teaching associate professionals & 4146 & 50.8 & 9182 & 57.2 \\
\hline 3320 & Pre-primary education teaching associate professionals & 17 & 0.2 & 1030 & 6.4 \\
\hline 3330 & Special education teaching associate professionals & 2082 & 25.5 & 4940 & 30.8 \\
\hline 3340 & Other teaching associate professionals & 1916 & 23.5 & 913 & 5.7 \\
\hline 34 & Other associate professionals & 60,868 & 100.0 & 38,950 & 100.0 \\
\hline 3411 & Securities and finance dealers and brokers & 416 & 0.7 & 133 & 0.3 \\
\hline
\end{tabular}


Table 5 Study population by sex and occupation in the 1991 Belgian census (Continued)

\begin{tabular}{|c|c|c|c|c|c|}
\hline ISCO & Occupational group in 1991 & M & $\mathrm{M} \%$ & $\mathrm{~F}$ & $\mathrm{~F} \%$ \\
\hline 3412 & Insurance representatives & 8283 & 13.6 & 2803 & 7.2 \\
\hline 3413 & Estate agents & 471 & 0.8 & 198 & 0.5 \\
\hline 3414 & Travel consultants and organisers & 861 & 1.4 & 537 & 1.4 \\
\hline 3415 & Technical and commercial sales representatives & 26,570 & 43.7 & 5386 & 13.8 \\
\hline 3416 & Buyers & 2747 & 4.5 & 1030 & 2.6 \\
\hline 3417 & Appraisers, valuers and auctioneers & 96 & 0.2 & 29 & 0.1 \\
\hline 3419 & Finance and sales associate professionals not elsewhere classified & 724 & 1.2 & 486 & 1.2 \\
\hline 3421 & Trade brokers & 924 & 1.5 & 299 & 0.8 \\
\hline 3422 & Clearing and forwarding agents & 209 & 0.3 & 42 & 0.1 \\
\hline 3431 & Administrative secretaries and related associate professionals & 438 & 0.7 & 9516 & 24.4 \\
\hline 3432 & Legal and related business associate professionals & 904 & 1.5 & 1449 & 3.7 \\
\hline 3433 & Bookkeepers & 5186 & 8.5 & 12,751 & 32.7 \\
\hline 3434 & Statistical, mathematical and related associate professionals & 109 & 0.2 & 152 & 0.4 \\
\hline 3441 & Customs and border inspectors & 1270 & 2.1 & 381 & 1.0 \\
\hline 3449 & $\begin{array}{l}\text { Customs, tax and related government associate professionals } \\
\text { not elsewhere classified }\end{array}$ & 2218 & 3.6 & 1269 & 3.3 \\
\hline 3450 & Police inspectors and detectives & 7246 & 11.9 & 363 & 0.9 \\
\hline 3471 & Decorators and commercial designers & 340 & 0.6 & 246 & 0.6 \\
\hline 3472 & Radio, television and other announcers & 461 & 0.8 & 564 & 1.4 \\
\hline 3474 & Clowns, magicians, acrobats and related associate professionals & 27 & 0.0 & 14 & 0.0 \\
\hline 3475 & Athletes, sportspersons and related associate professionals & 1368 & 2.2 & 1302 & 3.3 \\
\hline 41 & Office clerks & 188,232 & 100.0 & 240,961 & 100.0 \\
\hline 4111 & Stenographers and typists & 5555 & 3.0 & 8392 & 3.5 \\
\hline 4112 & Word-processor and related operators & 426 & 0.2 & 414 & 0.2 \\
\hline 4113 & Data entry operators & 1990 & 1.1 & 3166 & 1.3 \\
\hline 4114 & Calculating-machine operators & 205 & 0.1 & 463 & 0.2 \\
\hline 4115 & Secretaries & 3513 & 1.9 & 40,178 & 16.7 \\
\hline 4121 & Accounting and bookkeeping clerks & 3743 & 2.0 & 4213 & 1.7 \\
\hline 4122 & Statistical and finance clerks & 21,858 & 11.6 & 19,280 & 8.0 \\
\hline 4131 & Stock clerks & 8981 & 4.8 & 2823 & 1.2 \\
\hline 4133 & Transport clerks & 2270 & 1.2 & 1084 & 0.4 \\
\hline 4141 & Library and filing clerks & 196 & 0.1 & 602 & 0.2 \\
\hline 4142 & Mail carriers and sorting clerks & 12,984 & 6.9 & 2525 & 1.0 \\
\hline 4143 & Coding, proof-reading and related clerks & 354 & 0.2 & 521 & 0.2 \\
\hline 4190 & Other office clerks & 126,157 & 67.0 & 157,300 & 65.3 \\
\hline 42 & Customer services clerks & 6566 & 100.0 & 24,995 & 100.0 \\
\hline 4211 & Cashiers and ticket clerks & 831 & 12.7 & 12,755 & 51.0 \\
\hline 4212 & Tellers and other counter clerks & 3351 & 51.0 & 3754 & 15.0 \\
\hline 4213 & Bookmakers and croupiers & 267 & 4.1 & 278 & 1.1 \\
\hline 4214 & Pawnbrokers and money-lenders & 1 & 0.0 & 1 & 0.0 \\
\hline 4215 & Debt-collectors and related workers & 262 & 4.0 & 200 & 0.8 \\
\hline 4221 & Travel agency and related clerks & 549 & 8.4 & 1207 & 4.8 \\
\hline 4222 & Receptionists and information clerks & 347 & 5.3 & 2125 & 8.5 \\
\hline 4223 & Telephone switchboard operators & 958 & 14.6 & 4675 & 18.7 \\
\hline
\end{tabular}


Table 5 Study population by sex and occupation in the 1991 Belgian census (Continued)

\begin{tabular}{|c|c|c|c|c|c|}
\hline ISCO & Occupational group in 1991 & M & $M \%$ & $\mathrm{~F}$ & $\mathrm{~F} \%$ \\
\hline 51 & Personal and protective services workers & 60,747 & 100.0 & 86,914 & 100.0 \\
\hline 5111 & Travel attendants and travel stewards & 303 & 0.5 & 840 & 1.0 \\
\hline 5112 & Transport conductors & 898 & 1.5 & 267 & 0.3 \\
\hline 5113 & Travel guides & 89 & 0.1 & 165 & 0.2 \\
\hline 5121 & Housekeepers and related workers & 1258 & 2.1 & 992 & 1.1 \\
\hline 5122 & Cooks & 9895 & 16.3 & 20,174 & 23.2 \\
\hline 5123 & Waiters, waitresses and bartenders & 5347 & 8.8 & 8952 & 10.3 \\
\hline 5131 & Child-care workers & 21 & 0.0 & 3125 & 3.6 \\
\hline 5132 & Institution-based personal care workers & 787 & 1.3 & 11,898 & 13.7 \\
\hline 5133 & Home-based personal care workers & 301 & 0.5 & 21,359 & 24.6 \\
\hline 5139 & Personal care and related workers not elsewhere classified & 80 & 0.1 & 336 & 0.4 \\
\hline 5141 & Hairdressers, barbers, beauticians and related workers & 4648 & 7.7 & 14,014 & 16.1 \\
\hline 5142 & Companions and valets & 186 & 0.3 & 2287 & 2.6 \\
\hline 5143 & Undertakers and embalmers & 426 & 0.7 & 142 & 0.2 \\
\hline 5149 & Other personal services workers not elsewhere classified & 13 & 0.0 & 36 & 0.0 \\
\hline 5161 & Fire-fighters & 4605 & 7.6 & 20 & 0.0 \\
\hline 5162 & Police officers & 16,712 & 27.5 & 861 & 1.0 \\
\hline 5163 & Prison guards & 2067 & 3.4 & 148 & 0.2 \\
\hline 5169 & Protective services workers not elsewhere classified & 13,111 & 21.6 & 1298 & 1.5 \\
\hline 52 & Salespersons and demonstrators & 23,881 & 100.0 & 68,484 & 100.0 \\
\hline 5210 & Fashion and other models & 121 & 0.5 & 1586 & 2.3 \\
\hline 5220 & Shop salespersons and demonstrators & 21,790 & 91.2 & 65,100 & 95.1 \\
\hline 5230 & Stall and market salespersons & 1970 & 8.2 & 1798 & 2.6 \\
\hline 61 & Skilled agricultural and related workers & 39,462 & 100.0 & 13,726 & 100.0 \\
\hline 6111 & Field crop and vegetable growers & 1231 & 3.1 & 722 & 5.3 \\
\hline 6112 & Tree and shrub crop growers & 749 & 1.9 & 182 & 1.3 \\
\hline 6113 & Gardeners, horticultural and nursery growers & 8460 & 21.4 & 1916 & 14.0 \\
\hline 6114 & Mixed-crop growers & 24,185 & 61.3 & 9844 & 71.7 \\
\hline 6121 & Dairy and livestock producers & 1503 & 3.8 & 600 & 4.4 \\
\hline 6122 & Poultry producers & 585 & 1.5 & 270 & 2.0 \\
\hline 6124 & Mixed-animal producers & 78 & 0.2 & 75 & 0.5 \\
\hline 6141 & Forestry workers and loggers & 1881 & 4.8 & 41 & 0.3 \\
\hline 6151 & Aquatic-life cultivation workers & 155 & 0.4 & 20 & 0.1 \\
\hline 6153 & Deep-sea fishery workers & 628 & 1.6 & 56 & 0.4 \\
\hline 71 & Extraction and building trades workers & 141,225 & 100.0 & 1700 & 100.0 \\
\hline 7111 & Miners and quarry workers & 3354 & 2.4 & 72 & 4.2 \\
\hline 7112 & Shot firers and blasters & 10 & 0.0 & 0 & 0.0 \\
\hline 7113 & Stone splitters, cutters and carvers & 1344 & 1.0 & 30 & 1.8 \\
\hline 7122 & Bricklayers and stonemasons & 27,467 & 19.4 & 112 & 6.6 \\
\hline 7123 & Concrete placers, concrete finishers and related workers & 2442 & 1.7 & 17 & 1.0 \\
\hline 7124 & Carpenters and joiners & 24,202 & 17.1 & 240 & 14.1 \\
\hline 7129 & $\begin{array}{l}\text { Building frame and related trades workers not elsewhere } \\
\text { classified }\end{array}$ & 13,917 & 9.9 & 292 & 17.2 \\
\hline 7131 & Roofers & 5029 & 3.6 & 25 & 1.5 \\
\hline
\end{tabular}


Table 5 Study population by sex and occupation in the 1991 Belgian census (Continued)

\begin{tabular}{|c|c|c|c|c|c|}
\hline$\overline{\mathrm{ISCO}}$ & Occupational group in 1991 & M & $\mathrm{M} \%$ & $\mathrm{~F}$ & $\mathrm{~F} \%$ \\
\hline 7132 & Floor layers and tile setters & 4017 & 2.8 & 35 & 2.1 \\
\hline 7133 & Plasterers & 3431 & 2.4 & 41 & 2.4 \\
\hline 7134 & Insulation workers & 1526 & 1.1 & 22 & 1.3 \\
\hline 7135 & Glaziers & 1160 & 0.8 & 93 & 5.5 \\
\hline 7136 & Plumbers and pipe fitters & 14,795 & 10.5 & 106 & 6.2 \\
\hline 7137 & Building and related electricians & 23,591 & 16.7 & 222 & 13.1 \\
\hline 7141 & Painters and related workers & 13,106 & 9.3 & 337 & 19.8 \\
\hline 7142 & Varnishers and related painters & 1363 & 1.0 & 49 & 2.9 \\
\hline 7143 & Building structure cleaners & 471 & 0.3 & 7 & 0.4 \\
\hline 72 & Metal, machinery and related trades workers & 136,747 & 100.0 & 11,611 & 100.0 \\
\hline 7212 & Welders and flamecutters & 20,187 & 14.8 & 668 & 5.8 \\
\hline 7213 & Sheet-metal workers & 6790 & 5.0 & 118 & 1.0 \\
\hline 7214 & Structural-metal preparers and erectors & 61,271 & 44.8 & 8327 & 71.7 \\
\hline 7215 & Riggers and cable splicers & 195 & 0.1 & 7 & 0.1 \\
\hline 7216 & Underwater workers & 51 & 0.0 & 2 & 0.0 \\
\hline 7221 & Blacksmiths, hammer-smiths and forging-press workers & 905 & 0.7 & 18 & 0.2 \\
\hline 7222 & Tool-makers and related workers & 2803 & 2.0 & 118 & 1.0 \\
\hline 7231 & Motor vehicle mechanics and fitters & 27,908 & 20.4 & 774 & 6.7 \\
\hline 7232 & Aircraft engine mechanics and fitters & 615 & 0.4 & 8 & 0.1 \\
\hline 7233 & Agricultural- or industrial-machinery mechanics and fitters & 7093 & 5.2 & 197 & 1.7 \\
\hline 7241 & Electrical mechanics and fitters & 6415 & 4.7 & 1234 & 10.6 \\
\hline 7242 & Electronics fitters & 1144 & 0.8 & 66 & 0.6 \\
\hline 7243 & Electronics mechanics and servicers & 663 & 0.5 & 48 & 0.4 \\
\hline 7244 & Telegraph and telephone installers and servicers & 332 & 0.2 & 11 & 0.1 \\
\hline 7245 & Electrical line installers, repairers and cable jointers & 375 & 0.3 & 15 & 0.1 \\
\hline 73 & Precision, handicraft, craft printing and related trades workers & 20,746 & 100.0 & 4665 & 100.0 \\
\hline 7311 & Precision-instrument makers and repairers & 1089 & 5.2 & 171 & 3.7 \\
\hline 7312 & Musical instrument makers and tuners & 82 & 0.4 & 3 & 0.1 \\
\hline 7313 & Jewellery and precious-metal workers & 3567 & 17.2 & 1127 & 24.2 \\
\hline 7321 & Abrasive wheel formers, potters and related workers & 1420 & 6.8 & 171 & 3.7 \\
\hline 7322 & Glass-makers, cutters, grinders and finishers & 3625 & 17.5 & 447 & 9.6 \\
\hline 7323 & Glass engravers and etchers & 52 & 0.3 & 20 & 0.4 \\
\hline 7324 & Glass, ceramics and related decorative painters & 40 & 0.2 & 60 & 1.3 \\
\hline 7331 & Handicraft workers in wood and related materials & 45 & 0.2 & 16 & 0.3 \\
\hline 7332 & Handicraft workers in textile, leather and related materials & 406 & 2.0 & 60 & 1.3 \\
\hline 7341 & Compositors, typesetters and related workers & 8179 & 39.4 & 1310 & 28.1 \\
\hline 7342 & Stereotypers and electrotypers & 96 & 0.5 & 65 & 1.4 \\
\hline 7343 & Printing engravers and etchers & 810 & 3.9 & 178 & 3.8 \\
\hline 7344 & Photographic and related workers & 246 & 1.2 & 159 & 3.4 \\
\hline 7345 & Bookbinders and related workers & 830 & 4.0 & 742 & 15.9 \\
\hline 7346 & Silk-screen, block and textile printers & 259 & 1.2 & 136 & 2.9 \\
\hline 74 & Other craft and related trades workers & 45,314 & 100.0 & 29,739 & 100.0 \\
\hline 7411 & Butchers, fishmongers and related food preparers & 15,553 & 34.3 & 3825 & 12.9 \\
\hline 7412 & Bakers, pastry-cooks and confectionery makers & 10,766 & 23.8 & 3587 & 12.1 \\
\hline
\end{tabular}


Table 5 Study population by sex and occupation in the 1991 Belgian census (Continued)

\begin{tabular}{|c|c|c|c|c|c|}
\hline ISCO & Occupational group in 1991 & M & $\mathrm{M} \%$ & $\mathrm{~F}$ & $\mathrm{~F} \%$ \\
\hline 7413 & Dairy-products makers & 61 & 0.1 & 20 & 0.1 \\
\hline 7414 & Fruit, vegetable and related preservers & 9 & 0.0 & 19 & 0.1 \\
\hline 7415 & Food and beverage tasters and graders & 8 & 0.0 & 0 & 0.0 \\
\hline 7416 & Tobacco preparers and tobacco products makers & 268 & 0.6 & 1051 & 3.5 \\
\hline 7421 & Wood treaters & 10 & 0.0 & 2 & 0.0 \\
\hline 7422 & Cabinet-makers and related workers & 9955 & 22.0 & 1245 & 4.2 \\
\hline 7423 & Woodworking-machine setters and setter-operators & 444 & 1.0 & 82 & 0.3 \\
\hline 7424 & Basketry weavers, brush makers and related workers & 85 & 0.2 & 27 & 0.1 \\
\hline 7431 & Fibre preparers & 315 & 0.7 & 147 & 0.5 \\
\hline 7432 & Weavers, knitters and related workers & 3481 & 7.7 & 1328 & 4.5 \\
\hline 7433 & Tailors, dressmakers and hatters & 489 & 1.1 & 6170 & 20.7 \\
\hline 7434 & Furriers and related workers & 58 & 0.1 & 68 & 0.2 \\
\hline 7435 & Textile, leather and related pattern-makers and cutters & 128 & 0.3 & 770 & 2.6 \\
\hline 7436 & Sewers, embroiderers and related workers & 925 & 2.0 & 10,312 & 34.7 \\
\hline 7437 & Upholsterers and related workers & 1216 & 2.7 & 287 & 1.0 \\
\hline 7441 & Pelt dressers, tanners and fellmongers & 94 & 0.2 & 67 & 0.2 \\
\hline 7442 & Shoe-makers and related workers & 1449 & 3.2 & 732 & 2.5 \\
\hline 81 & Stationary plant and related operators & 23,831 & 100.0 & 2086 & 100.0 \\
\hline 8111 & Mining-plant operators & 179 & 0.8 & 0 & 0.0 \\
\hline 8112 & Mineral-ore- and stone-processing-plant operators & 168 & 0.7 & 0 & 0.0 \\
\hline 8113 & Well drillers and borers and related workers & 453 & 1.9 & 4 & 0.2 \\
\hline 8121 & Ore and metal furnace operators & 993 & 4.2 & 7 & 0.3 \\
\hline 8122 & Metal melters, casters and rolling-mill operators & 4383 & 18.4 & 171 & 8.2 \\
\hline 8123 & Metal-heat-treating-plant operators & 59 & 0.2 & 1 & 0.0 \\
\hline 8124 & Metal drawers and extruders & 1698 & 7.1 & 329 & 15.8 \\
\hline 8131 & Glass and ceramics kiln and related machine operators & 106 & 0.4 & 3 & 0.1 \\
\hline 8141 & Wood-processing-plant operators & 1222 & 5.1 & 62 & 3.0 \\
\hline 8142 & Paper-pulp plant operators & 15 & 0.1 & 3 & 0.1 \\
\hline 8143 & Papermaking-plant operators & 3010 & 12.6 & 736 & 35.3 \\
\hline 8151 & Crushing-, grinding- and chemical-mixing machinery operators & 480 & 2.0 & 11 & 0.5 \\
\hline 8152 & Chemical-heat-treating-plant operators & 206 & 0.9 & 13 & 0.6 \\
\hline 8153 & Chemical-filtering- and separating-equipment operators & 25 & 0.1 & 1 & 0.0 \\
\hline 8154 & $\begin{array}{l}\text { Chemical-still and reactor operators (except petroleum and } \\
\text { natural gas) }\end{array}$ & 61 & 0.3 & 2 & 0.1 \\
\hline 8155 & Petroleum- and natural-gas-refining-plant operators & 35 & 0.1 & 2 & 0.1 \\
\hline 8159 & Chemical-processing-plant operators not elsewhere classified & 8313 & 34.9 & 493 & 23.6 \\
\hline 8161 & Power-production plant operators & 947 & 4.0 & 102 & 4.9 \\
\hline 8162 & Steam-engine and boiler operators & 669 & 2.8 & 31 & 1.5 \\
\hline 8163 & Incinerator, water-treatment and related plant operators & 30 & 0.1 & 0 & 0.0 \\
\hline 8171 & Automated-assembly-line operators & 706 & 3.0 & 100 & 4.8 \\
\hline 8172 & Industrial-robot operators & 73 & 0.3 & 15 & 0.7 \\
\hline 82 & Machine operators and assemblers & 41,942 & 100.0 & 29,982 & 100.0 \\
\hline 8211 & Machine-tool operators & 7612 & 18.1 & 169 & 0.6 \\
\hline 8212 & Cement and other mineral products machine operators & 362 & 0.9 & 5 & 0.0 \\
\hline
\end{tabular}


Table 5 Study population by sex and occupation in the 1991 Belgian census (Continued)

\begin{tabular}{|c|c|c|c|c|c|}
\hline$\overline{\mathrm{ISCO}}$ & Occupational group in 1991 & M & $\mathrm{M} \%$ & $\mathrm{~F}$ & $\mathrm{~F} \%$ \\
\hline 8221 & Pharmaceutical- and toiletry-products machine operators & 974 & 2.3 & 855 & 2.9 \\
\hline 8222 & Ammunition- and explosive-products machine operators & 15 & 0.0 & 11 & 0.0 \\
\hline 8223 & Metal finishing-, plating- and coating-machine operators & 432 & 1.0 & 58 & 0.2 \\
\hline 8224 & Photographic-products machine operators & 133 & 0.3 & 21 & 0.1 \\
\hline 8229 & Chemical-products machine operators not elsewhere classified & 5811 & 13.9 & 1193 & 4.0 \\
\hline 8231 & Rubber-products machine operators & 685 & 1.6 & 56 & 0.2 \\
\hline 8232 & Plastic-products machine operators & 859 & 2.0 & 250 & 0.8 \\
\hline 8240 & Wood-products machine operators & 307 & 0.7 & 35 & 0.1 \\
\hline 8251 & Printing-machine operators & 3328 & 7.9 & 955 & 3.2 \\
\hline 8252 & Bookbinding-machine operators & 1 & 0.0 & 0 & 0.0 \\
\hline 8253 & Paper-products machine operators & 386 & 0.9 & 199 & 0.7 \\
\hline 8261 & Fibre-preparing-, spinning- and winding-machine operators & 850 & 2.0 & 2563 & 8.5 \\
\hline 8262 & Weaving- and knitting-machine operators & 708 & 1.7 & 475 & 1.6 \\
\hline 8263 & Sewing-machine operators & 275 & 0.7 & 6707 & 22.4 \\
\hline 8264 & Bleaching-, dyeing- and cleaning-machine operators & 1105 & 2.6 & 1661 & 5.5 \\
\hline 8265 & Fur- and leather-preparing-machine operators & 124 & 0.3 & 21 & 0.1 \\
\hline 8266 & Shoemaking- and related machine operators & 49 & 0.1 & 88 & 0.3 \\
\hline 8271 & Meat- and fish-processing-machine operators & 30 & 0.1 & 9 & 0.0 \\
\hline 8272 & Dairy-products machine operators & 1133 & 2.7 & 250 & 0.8 \\
\hline 8273 & Grain- and spice-milling-machine operators & 410 & 1.0 & 25 & 0.1 \\
\hline 8274 & Baked-goods, cereal and chocolate-products machine operators & 561 & 1.3 & 199 & 0.7 \\
\hline 8275 & Fruit-, vegetable- and nut-processing-machine operators & 1764 & 4.2 & 174 & 0.6 \\
\hline 8276 & Sugar production machine operators & 385 & 0.9 & 44 & 0.1 \\
\hline 8277 & Tea-, coffee-, and cocoa-processing-machine operators & 184 & 0.4 & 19 & 0.1 \\
\hline 8278 & Brewers-, wine and other beverage machine operators & 509 & 1.2 & 40 & 0.1 \\
\hline 8279 & Tobacco production machine operators & 63 & 0.2 & 80 & 0.3 \\
\hline 8281 & Mechanical-machinery assemblers & 3485 & 8.3 & 271 & 0.9 \\
\hline 8282 & Electrical-equipment assemblers & 1655 & 3.9 & 868 & 2.9 \\
\hline 8283 & Electronic-equipment assemblers & 516 & 1.2 & 126 & 0.4 \\
\hline 8284 & Metal-, rubber- and plastic-products assemblers & 3187 & 7.6 & 688 & 2.3 \\
\hline 8285 & Wood and related products assemblers & 6 & 0.0 & 1 & 0.0 \\
\hline 8286 & Paperboard, textile and related products assemblers & 26 & 0.1 & 30 & 0.1 \\
\hline 8290 & Other machine operators and assemblers & 4012 & 9.6 & 11,836 & 39.5 \\
\hline 83 & Drivers and mobile plant operators & 103,341 & 100.0 & 2695 & 100.0 \\
\hline 8311 & Locomotive-engine drivers & 4478 & 4.3 & 14 & 0.5 \\
\hline 8312 & Railway brakers, signallers and shunters & 3167 & 3.1 & 52 & 1.9 \\
\hline 8322 & Car, taxi and van drivers & 11,832 & 11.4 & 614 & 22.8 \\
\hline 8323 & Bus and tram drivers & 9786 & 9.5 & 628 & 23.3 \\
\hline 8324 & Heavy truck and lorry drivers & 49,177 & 47.6 & 781 & 29.0 \\
\hline 8331 & Motorised farm and forestry plant operators & 65 & 0.1 & 1 & 0.0 \\
\hline 8332 & Earth-moving- and related plant operators & 3924 & 3.8 & 30 & 1.1 \\
\hline 8333 & Crane, hoist and related plant operators & 7882 & 7.6 & 30 & 1.1 \\
\hline 8334 & Lifting-truck operators & 12,036 & 11.6 & 499 & 18.5 \\
\hline 8340 & Ships' deck crews and related workers & 994 & 1.0 & 46 & 1.7 \\
\hline
\end{tabular}


Table 5 Study population by sex and occupation in the 1991 Belgian census (Continued)

\begin{tabular}{|c|c|c|c|c|c|}
\hline $\mathrm{ISCO}$ & Occupational group in 1991 & M & $\mathrm{M} \%$ & $\mathrm{~F}$ & $\mathrm{~F} \%$ \\
\hline 91 & Services elementary occupations & 63,630 & 100.0 & 119,135 & 100.0 \\
\hline 9112 & Street vendors, non-food products & 2905 & 4.6 & 1635 & 1.4 \\
\hline 9120 & $\begin{array}{l}\text { Shoe cleaning and other street services elementary } \\
\text { occupations }\end{array}$ & 3 & 0.0 & 10 & 0.0 \\
\hline 9131 & Domestic helpers and cleaners & 1043 & 1.6 & 51,649 & 43.4 \\
\hline 9132 & $\begin{array}{l}\text { Helpers and cleaners in offices, hotels and other } \\
\text { establishments }\end{array}$ & 46,727 & 73.4 & 25,131 & 21.1 \\
\hline 9133 & Hand-launderers and pressers & 577 & 0.9 & 4458 & 3.7 \\
\hline 9141 & Building caretakers & 1392 & 2.2 & 2963 & 2.5 \\
\hline 9142 & Vehicle, window and related cleaners & 3651 & 5.7 & 28,838 & 24.2 \\
\hline 9151 & Messengers, package and luggage porters and deliverers & 40 & 0.1 & 14 & 0.0 \\
\hline 9152 & Doorkeepers, watchpersons and related workers & 2349 & 3.7 & 4204 & 3.5 \\
\hline 9153 & $\begin{array}{l}\text { Vending-machine money collectors, meter readers and } \\
\text { related workers }\end{array}$ & 438 & 0.7 & 94 & 0.1 \\
\hline 9161 & Garbage collectors & 4210 & 6.6 & 134 & 0.1 \\
\hline 9162 & Sweepers and related labourers & 295 & 0.5 & 5 & 0.0 \\
\hline 92 & Agricultural and related labourers & 444 & 100.0 & 2242 & 100.0 \\
\hline 9211 & Farm-hands and labourers & 439 & 98.9 & 2242 & 100.0 \\
\hline 9212 & Forestry labourers & 5 & 1.1 & 0 & 0.0 \\
\hline 93 & Labourers in mining, construction, manufacturing and transport & 83,206 & 100.0 & 14,189 & 100.0 \\
\hline 9311 & Mining and quarrying labourers & 73 & 0.1 & 0 & 0.0 \\
\hline 9312 & $\begin{array}{l}\text { Construction and maintenance labourers: roads, dams and } \\
\text { similar constructions }\end{array}$ & 11,058 & 13.3 & 89 & 0.6 \\
\hline 9321 & Assembling labourers & 6243 & 7.5 & 5016 & 35.4 \\
\hline 9322 & Hand packers and other manufacturing labourers & 8452 & 10.2 & 152 & 1.1 \\
\hline 9333 & Freight handlers & 57,380 & 69.0 & 8932 & 63.0 \\
\hline 110 & Armed forces & 25,228 & 100.0 & 1950 & 100.0 \\
\hline
\end{tabular}

\section{Abbreviations}

Cl: 95\% Confidence Intervals; OR: Odds Ratio; SEP: Socio-Economic Position

\section{Acknowledgements}

We would like to thank Statistics Belgium for performing the linkage procedure. The authors would like to thank Dr. Katrien Vanthomme for her thoughtful advice during the writing process.

\section{Funding}

$\mathrm{LVdB}$ is a PhD fellow at the Research Foundation-Flanders (FWO).

\section{Availability of data and materials}

The data that support the findings of this study are available from Statistics Belgium but restrictions apply to the availability of these data, which were used under license for the current study, and so are not publicly available.

\section{Authors' contributions}

PD and LVdB designed the study. LVdB conducted the study and wrote the first draft of the manuscript. Both authors edited the draft, discussed the interpretation and approved the final version of the manuscript.

\section{Ethics approval and consent to participate}

Permission for analyses were granted after verification of the research goals by the Belgian Commission for the protection of privacy.

\section{Consent for publication}

Not applicable.

\section{Competing interests}

The authors declare that they have no conflict of interest.

\section{Publisher's Note}

Springer Nature remains neutral with regard to jurisdictional claims in published maps and institutional affiliations.

Received: 2 July 2018 Accepted: 20 September 2018

Published online: 08 November 2018

\section{References}

1. van den Berg TIJ, Elders LAM, Burdorf A. Influence of health and work on early retirement. J Occup Environ Med. 2010;52:576-83. https://doi.org/10. 1097/JOM.0b013e3181de8133.

2. Morefield B, Ribar DC, Ruhm CJ. Occupational status and health transitions. The BE Journal of Economic Analysis \& Policy. 2012;11. https://doi.org/10. 1515/1935-1682.2881.

3. Fletcher JM. The effects of first occupation on long term health status: evidence from the Wisconsin longitudinal study. J Labor Res. 2012;33:49-75. https://doi.org/10.1007/s12122-011-9121-x.

4. Case A, Deaton AS. Broken down by work and sex: How our health declines. Analyses in the Economics of Aging, University of Chicago Press; 2005. p. 185-212.

5. Gueorguieva R, Sindelar JL, Falba TA, Fletcher JM, Keenan P, Wu R, et al. The impact of occupation on self-rated health: cross-sectional and longitudinal evidence from the health and retirement survey. J Gerontol Ser B Psychol Sci Soc Sci. 2009;64B:118-24. https://doi.org/10.1093/geronb/gbn006. 
6. Cambois E, Laborde C, Romieu I, Robine J-M. Occupational inequalities in health expectancies in France in the early 2000s: unequal chances of reaching and living retirement in good health. Demogr Res. 2011;25:407-36. https://doi.org/10.4054/DemRes.2011.25.12.

7. Myrskylä M, Leinonen T, Martikainen P. Life expectancy by labor force status and social class: recent period and cohort trends and projections for Finland. Finnish centre for pensions: Helsinki; 2013.

8. Van den Borre L, Deboosere P. Enduring health effects of asbestos use in Belgian industries: a record-linked cohort study of cause-specific mortality (2001-2009). BMJ Open. 2015;5:1-10. https:/doi.org/10.1136/bmjopen-2014-007384.

9. Vandenplas O, Lantin A-C, D'Alpaos V, Larbanois A, Hoet P, Vandeweerdt M, et al. Time trends in occupational asthma in Belgium. Respir Med. 2011;105: 1364-72. https://doi.org/10.1016/j.rmed.2011.05.002.

10. Derycke H, Clays E, Vlerick P, D'Hoore W, Hasselhorn HM, Braeckman L. Perceived work ability and turnover intentions: a prospective study among Belgian healthcare workers. J Adv Nurs. 2012;68:1556-66. https://doi.org/10. 1111/j.1365-2648.2012.05961.x.

11. Van Droogenbroeck F, Spruyt B. Do teachers have worse mental health? Review of the existing comparative research and results from the Belgian health interview survey. Teach Teach Educ. 2015;51:88-100. https://doi.org/ 10.1016/j.tate.2015.06.006.

12. Pelfrene E, Vlerick P, Kittel F, Mak RP, Kornitzer M, Backer GD. Psychosocial work environment and psychological well-being: assessment of the buffering effects in the job demand-control (-support) model in BELSTRESS. Stress Health. 2002;18:43-56. https://doi.org/10.1002/smi.920.

13. Vanroelen C, Levecque K, Moors G, Louckx F. Linking credentialed skills, social class, working conditions and self-reported health: a focus on health inequality-generating mechanisms. Sociol Health IIIn. 2010;32:948-64. https://doi.org/10.1111/j.1467-9566.2010.01260.x.

14. Idler EL, Hudson SV, Leventhal H. The meanings of self-ratings of health: a qualitative and quantitative approach. Res Aging. 1999;21:458-76. https:// doi.org/10.1177/0164027599213006.

15. Benjamins MR, Hummer RA, Eberstein IW, Nam CB. Self-reported health and adult mortality risk: an analysis of cause-specific mortality. Soc Sci Med. 2004;59:1297-306. https://doi.org/10.1016/j.socscimed.2003.01.001.

16. Deboosere P, Gadeyne S. De Nationale Databank Mortaliteit Aanmaak van een databank voor onderzoek van differentiële sterfte naar socioeconomische status en leefvorm. Working Paper Steunpunt Demografie. 1999;1999-7:1-29.

17. Elias P. Occupational classification (ISCO-88): concepts, Methods, Reliability, Validity and Cross-National Comparability. OECD Publishing; 1997.

18. Schütte S, Chastang J-F, Parent-Thirion A, Vermeylen G, Niedhammer I. Association between socio-demographic, psychosocial, material and occupational factors and self-reported health among workers in Europe. J Public Health. 2014;36:194-204. https://doi.org/10.1093/pubmed/fdt050.

19. Olsen KM, Dahl S-A. Health differences between European countries. Soc Sci Med. 2007;64:1665-78. https://doi.org/10.1016/j.socscimed.2006.11.031.

20. Steenland K, Stayner $L$. The importance of employment status in occupational cohort mortality studies. Epidemiology. 1991;2:418-23.

21. Borgonovi F, Pokropek A. Education and self-reported health: evidence from 23 countries on the role of years of schooling, cognitive skills and social capital. PLoS One. 2016;11. https://doi.org/10.1371/journal.pone.0149716.

22. Veenstra G. Social capital, SES and health: an individual-level analysis. Soc Sci Med. 2000;50:619-29. https://doi.org/10.1016/S0277-9536(99)00307-X.

23. Kunst AE, Bos V, Lahelma E, Bartley M, Lissau I, Regidor $E$, et al. Trends in socioeconomic inequalities in self-assessed health in 10 European countries. Int J Epidemiol. 2005;34:295-305. https://doi.org/10.1093/ije/dyh342.

24. Adler NE, Boyce T, Chesney MA, Cohen S, Folkman S, Kahn RL, et al. Socioeconomic status and health. The challenge of the gradient. Am Psychol. 1994;49:15-24

25. Wilkinson R, Marmot M, editors. The solid facts. Copenhagen, Denmark: WHO; 1998.

26. Richiardi L, Barone-Adesi F, Merletti F, Pearce N. Using directed acyclic graphs to consider adjustment for socioeconomic status in occupational cancer studies. J Epidemiol Community Health. 2008;62:e14. https://doi.org/ 10.1136/jech.2007.065581.

27. Krieger J, Higgins DL. Housing and health: time again for public health action. Am J Public Health. 2002;92:758-68. https://doi.org/10.2105/AJPH. 92.5.758.

28. Vanneste D, Thomas I, Goossens L. Woning en woonomgeving in België. FOD Economie \& Federaal Wetenschapsbeleid: Brussel; 2007.
29. Li CY, Sung FC. A review of the healthy worker effect in occupational epidemiology. Occup Med. 1999:49:225-9. https://doi.org/10.1093/occmed/ 49.4.225.

30. Niedhammer I, Chastang J-F, David S, Kelleher C. The contribution of occupational factors to social inequalities in health: findings from the national French SUMER survey. Soc Sci Med. 2008;67:1870-81. https://doi. org/10.1016/j.socscimed.2008.09.007.

31. De Moortel D, Vandenheede H, Carles M, Vanroelen C. Structural and intermediary determinants of social inequalities in the mental well-being of European workers: a relational approach. BMC Public Health 2014;14:938.

32. Borrell C, Muntaner C, Benach J, Artazcoz L. Social class and self-reported health status among men and women: what is the role of work organisation, household material standards and household labour? Soc Sci Med. 2004;58:1869-87. https://doi.org/10.1016/S0277-9536(03)00408-8.

33. Schrijvers $C T$, van de Mheen $H$, Stronks K, Mackenbach JP. Socioeconomic inequalities in health in the working population: the contribution of working conditions. Int J Epidemiol 1998;27:1011-1018. doi:https://doi.org/ 10.1093/ije/27.6.1011.

34. Lorant V, Demarest S, Miermans P-J, Van Oyen H. Survey error in measuring socio-economic risk factors of health status: a comparison of a survey and a census. Int J Epidemiol. 2007;36:1292-9. https://doi.org/10.1093/ije/dym191.

35. Pekkala J, Blomgren J, Pietiläinen O, Lahelma E, Rahkonen O. Occupational class differences in long sickness absence: a register-based study of 2.1 million Finnish women and men in 1996-2013. BMJ Open. 2017;7:e014325. https://doi.org/10.1136/bmjopen-2016-014325.

36. Ihlebaek C. Occupational and social variation in subjective health complaints. Occup Med. 2003;53:270-8. https://doi.org/10.1093/occmed/kqg060.

37. Baillargeon J, Wilkinson G, Rudkin L, Baillargeon G, Ray L. Characteristics of the healthy worker effect: a comparison of male and female occupational cohorts. J Occup Environ Med. 1998;40:368-73.

38. Miilunpalo S, Vuori I, Oja P, Pasanen M, Urponen $\mathrm{H}$. Self-rated health status as a health measure: the predictive value of self-reported health status on the use of physician services and on mortality in the working-age population. J Clin Epidemiol. 1997;50:517-28. https://doi.org/10.1016/S08954356(97)00045-0.

39. Pearce N, Checkoway H, Shy C. Time-related factors as potential confounders and effect modifiers in studies based on an occupational cohort. Scand J Work Environ Health. 1986;12:97-107. https://doi.org/10. 5271/sjweh.2161.

40. Mortelmans D, Vannieuwenhuyze JTA. The age-dependent influence of selfreported health and job characteristics on retirement. Int J Public Health. 2013;58:13-22. https://doi.org/10.1007/s00038-012-0411-8.

41. Ki M, Sacker A, Kelly Y, Nazroo J. Health selection operating between classes and across employment statuses. J Epidemiol Community Health. 2011;65: 1132-9. https://doi.org/10.1136/jech.2009.107995.

42. Rosenthal L, Carroll-Scott A, Earnshaw VA, Santilli A, Ickovics JR. The importance of full-time work for urban adults' mental and physical health. Soc Sci Med. 2012;75:1692-6. https://doi.org/10.1016/j.socscimed.2012.07.003.

43. Bartoll X, Cortès I, Artazcoz L. Full- and part-time work: gender and welfaretype differences in European working conditions, job satisfaction, health status, and psychosocial issues. Scand J Work Environ Health. 2014;40:370-9. https://doi.org/10.5271/sjweh.3429.

44. Burgard SA, Lin KY. Bad jobs, bad health? How work and working conditions contribute to health disparities. Am Behav Sci. 2013;57. https://doi.org/10.1177/0002764213487347.

45. Bonoli G. Labour market and social protection reforms in international perspective: parallel or converging tracks? Taylor \& Francis; 2017.

46. The World Bank. Labor force participation rate. In: Female (\% of female population ages 15+) (modeled ILO estimate); 2018.

47. Statbel. Internationale standaard beroepen classificatie 2018. https://statbel. fgov.be/nl/over-statbel/methodologie/classificaties/internationale-standaardberoepen-classificatie-isco-08 (Accessed 1 March 2018). 